\title{
ROCK GLACIER AND PROTALUS RAMPART INVENTORY IN LAS SALINAS RIVER BASIN, CENTRAL ANDES OF ARGENTINA
}

\author{
ANA PAULA FORTE ${ }^{1,2^{*}}$, CRISTIAN DANIEL VILLARROEL ${ }^{1,2,}$ \\ MARÍA YANINA ESPER ANGILLIERI ${ }^{2}$
}

\author{
${ }^{1}$ Facultad de Ciencias Exactas y Naturales (FCEN), \\ Universidad Nacional de Cuyo (UNCuyo), Argentina. \\ ${ }^{2}$ Centro de Investigaciones de la Geosfera y la Biósfera (CIGEOBIO), Centro de Ciencia y Técnica de \\ San Juan (CCT - San Juan), Universidad Nacional de San Juan - CONICET, \\ Av. Ignacio de la Roza 590 (O), Complejo Universitario «Islas Malvinas», \\ Rivadavia, San Juan, CPA: J5402DCS, Argentina.
}

\begin{abstract}
This paper presents a detailed rock glacier and protalus rampart inventory from Las Salinas river basin, an arid subtropical mountain hydrological system (between $31^{\circ} 02^{\prime}$ and $31^{\circ} 22^{\prime} \mathrm{S}$ latitude) located in the northern sector of the Central Andes of Argentina, where permafrost and cryogenic processes prevail. The inventory is based on a geomorphological characterization by means of optical remote sensing and field description data. The study region covers $630 \mathrm{~km}^{2}$, with $3.25 \%$ of the area containing $405 \pm 8.2$ rock glaciers and protalus ramparts in total, of which $231 \pm 2.5$ are considered protalus rampart and $49 \pm 2$ are considered active, $61 \pm 1$ inactive and $64 \pm 3$ fossil rock glaciers. Frequency ratio and logistic regression were used as statistical methods to determine the relationship between the distribution of these periglacial landforms and different geological, morphometric and climatic variables as elevation, potential incoming solar radiation, slope, aspect and lithology. Results show that elevation, lithology, and aspect are the most influencing factors for the occurrence of active rock glaciers. According to rock glaciers and protalus ramparts distribution, the permafrost occurrence probability is above 3690 $\mathrm{m}$ a.s.l. (current and high periglacial environment). However, some inactive rock glaciers and protalus rampart were found below this elevation, thus between 3300 and $3690 \mathrm{~m}$ a.s.l. the landscapes are dominated by an unstable periglacial environment.
\end{abstract}

\section{Inventario de glaciares rocosos y protalus rampart en la cuenca del río Las Salinas, Andes centrales argentinos.}

RESUMEN. Este artículo presenta un inventario detallado de glaciares rocosos y protalus rampart en la cuenca del río Las Salinas, un sistema hidrológico de montaña subtropical (entre $31^{\circ} 02^{\prime}$ y $31^{\circ} 22^{\prime} \mathrm{S}$ de latitud), localizado en el sector septentrional de los Andes centrales de Argentina, donde predominan el permafrost y los procesos criogénicos. El inventario se basa en una caracterización geomorfológica mediante teledetección óptica y datos de descripción de campo. La región cubre $630 \mathrm{~km}^{2}$. Un 3,25\% del área contiene un total de 405 $\pm 8,2$ glaciares rocosos y protalus rampart, de los que $231 \pm 2,5$ pueden considerarse protalus rampart, $49 \pm 2$ pueden catalogarse como activos, $61 \pm 1$ inactivos y $64 \pm 3$ glaciares rocosos fósiles. Ratio de frecuencias y regresión logística se utilizaron como métodos estadísticos para determinar la relación entre la distribución de estas formas periglaciares y diferentes variables geológicas, morfométricas y climáticas como la altitud, radiación solar entrante potencial, pendiente, exposición y litología. Los resultados muestran que la altitud, la litología y la exposición son los factores más influyentes en la aparición de glaciares rocosos activos. Según la distribución de los glaciares rocosos y protalus rampart, el permafrost se sitúa por encima de los $3690 \mathrm{~m}$ s.n.m. (medioambiente periglacial actual). Sin embargo, por debajo de esta elevación se encontraron algunos glaciares rocosos y protalus rampart inactivos, por lo que entre los 3300 y 3690 m s.n.m., los paisajes están dominados por un ambiente periglacial inestable. 
Key words: Rock glacier, mountain permafrost, protalus rampart, Central Andes of Argentina, environmental variables.

Palabras clave: Glaciar rocoso, permafrost de montaña, protalus rampart, Andes centrales argentinos, variables ambientales.

Received: 6 November 2020

Accepted: 7 February 2021

\begin{abstract}
*Corresponding author: Ana P. Forte, Centro de Investigaciones de la Geosfera y la Biósfera (CIGEOBIO), Centro de Ciencia y Técnica de San Juan (CCT - San Juan), Universidad Nacional de San Juan - CONICET. Av. Ignacio de la Roza 590 (O), Complejo Universitario «Islas Malvinas», Rivadavia, San Juan, CPA: J5402DCS, Argentina. Email address: anapau.forte@gmail.com
\end{abstract}

\title{
1. Introduction
}

Cryospheric science shows a special interest in regions of arid mountain ranges, such as the Central Andes of Argentina, where permafrost and periglacial processes are prevalent. A reason for this is that periglacial environments are one of the main hydrological resource suppliers (Ohlanders et al., 2013). More specifically, intact rock glaciers and protalus ramparts are considered solid water reserves (Scapozza et al., 2011; Jones et al., 2018; Villarroel et al., 2020) and indicators of mountain permafrost (Barsch D., 1996; Haeberli et al., 2010).

Rock glaciers are periglacial landforms comprised of debris and interstitial ice, ice lenses or even massive ice bodies. They have a root zone (upper part) with a moderate incline and a frontal slope (lower part) with a very steep hillside (Barsch, 1996; Haeberli et al., 2010). Being an expression of creeping mountain permafrost, they are constituted by a permafrost core and a surface layer (active layer) that is in contact with the atmosphere. Some rock glaciers have an intermediate layer (transition layer), which at times acts as part of the permafrost and at other times as a part of the active layer. Whereas, protalus ramparts are periglacial landforms that are typically smaller than rock glaciers and exhibit a greater width/length ratio. They have a pronounced frontal slope and superficially do not show ridges and furrows superficially. They have been mentioned as the result of ice rich ground creep (Colucci et al., 2016) and some authors deem them as embryonic rock glaciers since they are also considered an expression of mountain permafrost (Barsch, 1996; Scapozza et al., 2011; Hedding, 2011; Scotti et al., 2013). Other authors associate the occurrence of protalus ramparts with the existence of old patches of perennial snow (Whalley and Azizi, 2003). In this work the definition provided by Barsch (1996) has been adopted.

Intact rock glaciers are classified as active and inactive based on their dynamics (Haeberli et al., 2010). Active rock glaciers show movement rates in the order of tens of centimeters per year, while inactive rock glaciers show almost no signs of surface movements (Roer and Nyenhuis, 2007; Kääb et al., 2007). The state of activity of the intact rock glaciers is closely related to their capacity as solidwater reserves (Azócar and Brenning, 2010; Jones et al., 2018, 2019) and to the degree of permafrost stability, given the surrounding environmental conditions (Kääb et al., 2007). Thus, their activity could be considered as a very accurate indicator of current climatic conditions and the state of the permafrost and the periglacial environment (stable or in degradation). However, climatic conditions in the past have also influenced the current distribution of rock glaciers (Haeberli et al., 2010, Jones et al, 2018).

The classification of rock glaciers as active, inactive and fossil is of great environmental significance; therefore, it is important to consider the highest number of criteria to reduce possible errors (Barsch, 1996; Haeberli et al., 2010; Ikeda and Matsuoka, 2006; Harrison et al., 2008; Esper Angillieri, 
2010, 2017; Jones et al., 2019). Active rock glaciers preserve and increase their ice content; whereas inactive rock glaciers, due to their unbalance with the environment, keep losing ice and, thus, are considered water sources. Moreover, rock glaciers that have lost all their ice content and indicate unfavorable periglacial environmental conditions, are called fossil, relict or pseudo-relict rock glaciers (Scotti et al., 2013; Colucci et al., 2019). Nevertheless, some periglacial processes could still exist around this kind of rock glaciers.

The Central Andes of Argentina mountain range is characterized by a wide periglacial environment development and for having the highest density of rock glaciers in the world (Trombotto et al., 2012). However, a detailed inventory along with descriptions of the landforms of the region is still scarce. This paper presents a rock glacier and protalus rampart inventory carried out in the northern sector of the Central Andes of Argentina, more specifically, in Las Salinas river basin, which encompasses the Frío, La Embarrada, El Bagre, and De Las Salinas or De Las Lagunas rivers. In the past decade, a number of rock glacier inventory surveys (Esper Angillieri, 2017; Trombotto et al., 2012; Villarroel and Forte, 2020; Tapia Baldis, 2018) and two regional studies (ING, 2016; Villarroel et al., 2018) have been conducted in nearby areas.

The relationship between environmental variables (climatic, lithological, topographic and morphometric) and the spatial distribution of rock glaciers is essential for conducting regional studies on periglacial environment distribution. Especially in the case of high mountain areas, where poor accessibility reduces the chances of obtaining climatic data, while it steeply increases the costs of systematic field studies. In this paper, we employ frequency ratio and logistic regression analyses as statistical methods. Various researches of this kind have been performed in other regions e.g.: Brenning (2005), Brenning and Trombotto (2006), Ikeda and Matsuoka (2006), Johnson et al. (2007) and Esper Angillieri (2010, 2017).

The results presented in this study will therefore prove to be a significant contribution to knowledge available on the number, features and distribution of rock glaciers and protalus ramparts in a scarcely studied sector of the Central Andes of Argentina. Furthermore, they could be useful for both regional and larger-scale assessments, mainly for permafrost distribution and geological risk studies.

\section{Regional setting}

The study region is Las Salinas river basin, which is situated on a northern sector of the Central Andes, in the Blanco river headwaters, covering about $13 \%$ of the Blanco river basin $\left(4861 \mathrm{~km}^{2}\right)$. Las Salinas basin includes the De Las Lagunas or De Las Salinas, El Bagre, La Embarrada and Frío river basins (Fig. 1). This hydrological system feeds north-western tributaries of the San Juan river basin, one of the two most important rivers of the region, with a total mean annual discharge of $56 \mathrm{~m}^{3} / \mathrm{s}$ (Subsecretaría de Recursos Hídricos, 2002). The Las Salinas river basin spreads over an area of 630 $\mathrm{km}^{2}$, with a total perimeter of $155 \mathrm{~km}$ and elevations between 2940 and $4750 \mathrm{~m}$ a.s.l. Its closing point is located at the geographical coordinates: $31^{\circ} 21.30^{\prime} \mathrm{S}$ and $70^{\circ} 23.35^{\prime} \mathrm{O}$, where the Salinas river flows into the Blanco river. 

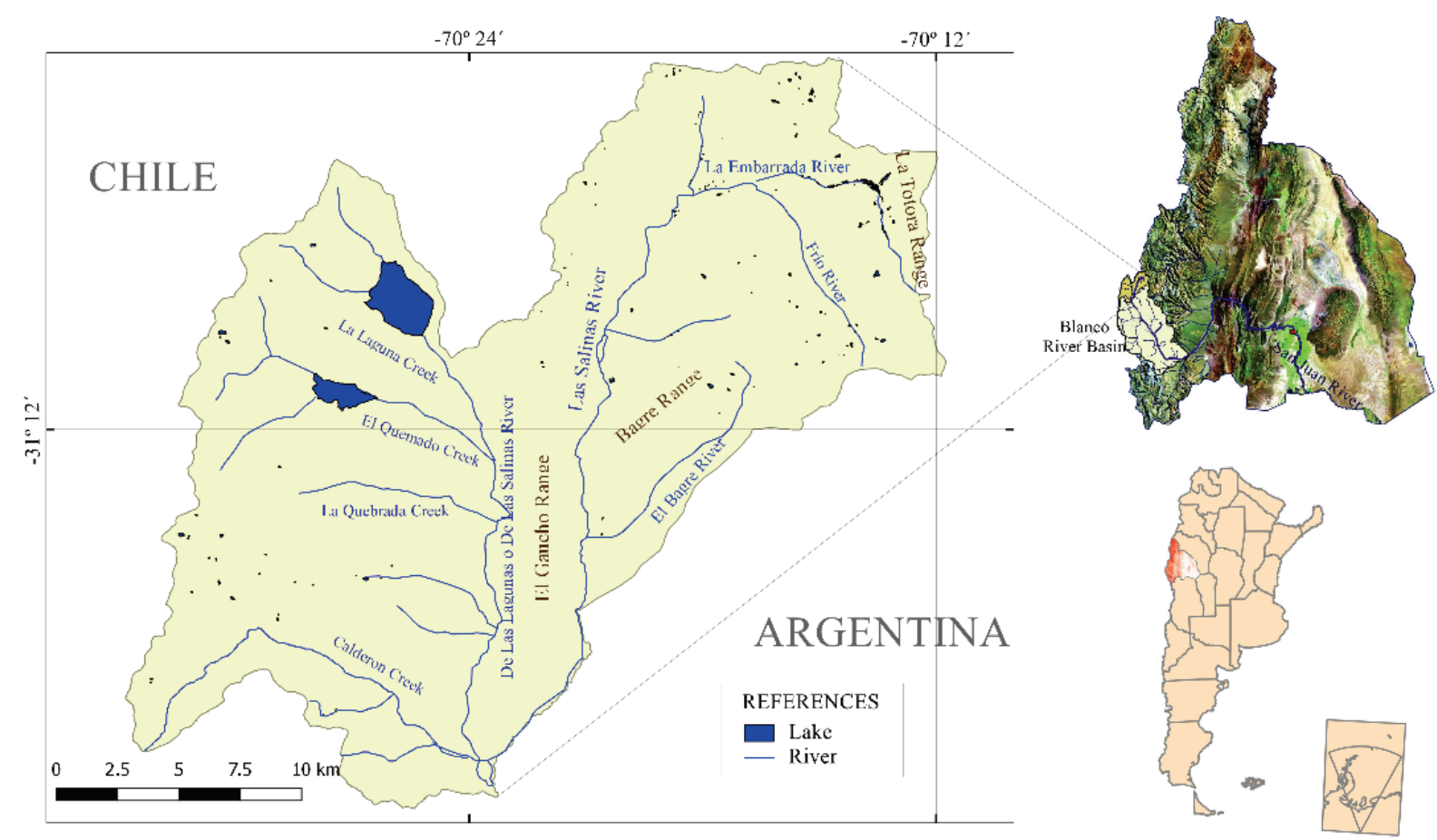

Figure 1. Location of Las Salinas river basin, part of Blanco river basin in the province of San Juan, Argentina

\subsection{Climatic and geomorphological setting}

The semi-arid climate of the study region, which lies on the rain shadow on the leeward side of the Andean Range, is influenced by the South American Arid Diagonal (Bruniard, 2014) and the interaction between the high-pressure systems of the Atlantic and Pacific Oceans (Rivera et al., 2013). Warm moist air collides and travels the Andes orography, which acts as a barrier for the moisture transfer from the Pacific (Strecker et al., 2007). Therefore, upon precipitations on the Chilean side, a dry and warm Föhn effect wind, starts blowing on the leeward side of the Andes mountain ranges. Annual moisture input in the region is highly variable, which correlates with the El Niño Southern Oscillation (or ENSO) phenomena (Corripio et al., 2007) and the wet atmospheric south-east masses coming from Atlantic winds. In the study area, the mean annual air temperature (MAAT) is $2.4^{\circ} \mathrm{C}$ at $3375 \mathrm{~m}$ a.s.l., based on measurements between April 2011 and February 2014 from three weather stations placed in the study area - two at El Altar and one at Los Azules mining projects (Schreiber 2015).

Other nearby meteorological stations indicate: a MAAT of $+0.59^{\circ} \mathrm{C}(3600 \mathrm{~m}$ a.s.l. during the period 1981-2003) at the Pachón meteorological station of Hydraulic Department of the government of San Juan (Villarroel, 2019); a MAAT of $+0.55^{\circ} \mathrm{C}(3740 \mathrm{~m}$ a.s.l. for the period 2009-2015) at the Pachón mining project meteorological station (Villarroel, 2019). While the General Water Directorate (DGA, Chile) in the upper portion of the Choapa valley indicates a MAAT of $+0.5^{\circ} \mathrm{C}$ at $3700 \mathrm{~m}$ a.s.l. (Monnier and Kinnard, 2013). It is worth noting that in Forte (2020) a regional isotherm of $0^{\circ} \mathrm{C}$ was calculated at $3800 \mathrm{~m}$ a.s.l. for the Central Andes.

In addition, the meteorological stations of the region show a mean annual precipitation value of $350 \mathrm{~mm}$ for an elevation of $4019 \mathrm{~m}$ a.s.l. (Portezuelo de la Guardia Station for the period 2009-2014; Tapia Baldis, 2018) and $297.6 \mathrm{~mm}$ for an elevation of $3600 \mathrm{~m}$ a.s.l. during the period 1981-2003, at the Pachón meteorological station of Hydraulic Department of the government of San Juan (Villarroel, 2019).

The relief in the Central Andes is mainly shaped by tectonic system activity (Strecker et al., 2007) and by Pleistocene glaciations (Forte and Villarroel, 2019; Palacios et al., 2020), thus, there are landforms caused by glacial erosion, e.g.: glacial striae, U-shaped and asymmetric valleys, smooth 
polished bedrocks, erratic blocks, cirques, rams, truncated spurs, edges, tarns, horns, hanging or suspended valleys, among others. Accumulation landforms conforming glacial deposits, such as moraines, erratic blocks or other sedimentary deposits (Till) are also frequently found. Currently, the glacial landscape is being modified and weathered by gravitational, fluvial, alluvial and periglacial processes. As regards periglacial landforms, there is a striking number of active, inactive and fossil rock glaciers, as well as other periglacial landforms such as protalus ramparts, solifluction hillsides, stones rings and belts, stratified slope waste deposits, convex-concave debris-mantled slopes and polygonal grounds. Furthermore, the local permafrost models show a high probability of permafrost occurrence in the study area (Esper Angillieri, 2017; Tapia Baldis, 2018). In this study area, lakes and lacustrine deposits are associated to moraines and mass wasting deposits. There is a noticeable change in the hydrological system below 3200 m a.s.1., where high Andean wetlands which grow on the foothills and lagoon systems (locally known as Vegas) has been identified.

\subsection{Geological setting}

The structural, topographic, stratigraphic and geological aspects of the region are highly dependent on the geometry of the Wadatti Benioff zone, where the interaction between the South American and Nazca tectonic plates takes place.

In the study area, Eo-Paleozoic rock deposits consist of strongly deformed Intrusive Rocks (DPig). Overlying the Paleozoic rocks, the Mesozoic deposits are found, which are mainly represented by the Choiyoi Group (Rolleri and Criado, 1970). This group is constituted by Permian-Triassic volcanic and pyroclastic rocks (PTrv) of alkaline composition, i.e. basalt, andesite, dacite and rhyolite rocks. The upper section of the group is characterized by aciditic association of intrusive and volcanic rocks (PTrg), consisting of gabbros, granodiorites and tonalities rocks. There is also a Jurassic and Lower Cretaceous marine sedimentary sequence ( $\mathrm{Jk}$-ism). The Cenozoic deposits are represented by Paleogene rocks (EOp and $\mathrm{OMp}$ ) in close relation with volcanic and plutonic events. In addition, there is a wide development of Neogene sedimentary and volcanic sequences (Ms and Mv) corresponding to the Lower Miocene. Finally, Quaternary deposits overlie the surface of the valleys (P1Qs), which consists mainly of glacial accumulation, proof of Pleistocene glacial advance and retreat sequences.

\section{Materials and methods}

In order to analyze the influence of environmental variables on the periglacial system, we applied a threefold approach: (1) Detailed mapping of rock glacier and protalus ramparts, (2) setup of a rock glacier inventory database, and (3) statistical analysis of rock glacier distribution.

The rock glacier and protalus ramparts inventory has been framed within the corresponding hydrological system. The network and basin drainage were mapped using a digital elevation model with a 12.5 x 12.5 m spatial resolution provided by ALOS Palsar (AP_07965_FBD_F6550). Rock glacier identification, classification, mapping and inventory were carried out based on geomorphological criteria (Roer and Nyenhuis, 2007) using field information and optical satellite imageries Terra/ASTER; CBERS2B/HRC; Sentinel 2; SPOT5 and SPOT 7. The landforms were manually (on-screen) digitized as vectors, using projection UTM zone 19 south and WGS84 datum. Mapping was performed on scenes from Autumn 2016, due to the diversity and good quality of the images available. Around $78 \%$ of the rock glacier and protalus rampart identifiers on optical images were checked on site.

For each rock glacier and protalus rampart mapped, the abrupt slope change in the root zone was considered as the upper limit. While the lower limit was delimitated by the marked slope change of the frontal and lateral talus.

The criterion used to distinguish protalus ramparts was their geomorphological characteristics: size (usually small), shape (similar width and length), steep frontal talus, smooth surfaces (no furrows and ridges structures); and their spatial location (frequently on steep slopes). 
The geomorphological criterion for identification and classification of rock glaciers included aspects as the degree of furrow and ridges development, slope angle of the frontal talus, presence/absence of vegetation, presence of springs, streams or bodies of liquid water on its surface or edges, weathering of exposed block faces and thermokarst occurrences. Rock glaciers were classified as fossil or relict and intact, the latter were subclassified as active and inactive.

- Active rock glaciers are characterized by a steep front talus $\left(>35^{\circ}\right)$, generally with exposure of fine debris and overlying loose boulders on the top and an accumulation of large boulders at the bottom (Ikeda and Matsuoka, 2006). Also, they show a pronounced development of furrow and ridges, evidence of on-going movement and are formed on favorable environmental conditions for the occurrence of geocryological processes (Haeberli et al., 2010).

- Inactive rock glaciers still contain ice but actually do not move and keep their shape. Unlike active rock glaciers, they do not show notable development of ridges and furrows on their surface. They are characterized by depressed surfaces, low angle talus slopes, and possibly by the presence of vegetation and collapsed structures. Ikeda and Matsuoka (2006) have considered talus slopes as criteria to classify a rock glacier: if the angle is less than $35^{\circ}$, it is inactive - in the case it is greater, it is active. As mentioned before, inactive rock glaciers still conserve ice, but their permafrost conditions are in a degradation state, so it is possible to find liquid water (springs, small streams or lagoons) and vegetation, as well as, collapse structures such as depressions or thermokarst.

- Fossil rock glaciers tend to have gentler slopes and a major collapsed surface due to ice melting. They have lost all their ice content and indicate current unfavorable environmental conditions for rock glacier or mountain permafrost development. The presence of vegetation on their surface is common, and their frontal talus has a lower angle and is also usually underdeveloped.

A detailed field control was conducted on the Frío, La Embarrada, Los Patos Norte and Bagres river basins and near the Salinas drainage. Geomorphological field studies allowed a clear characterization of the periglacial landforms, especially to detect vegetation, collapse structures, weathering blocks, springs and other geomorphological structures and processes. Field controls were conducted by late summer and early autumn (March and April), because in that period the area was clear of snow, which facilitated fieldwork.

Some of the geomorphological criteria used, in exceptional cases, may present ambiguities, for example active rock glaciers with depressions product of collapse or fossil rock glaciers without such depression, can be sometimes found. However, though this method of classifying rock glaciers may present errors, it has been shown to be a fairly accurate approach. In order to assess the rock glacier and protalus rampart inventory, an uncertainty study was performed. The processes of identification, classification and mapping of periglacial landforms were carried out by two different individuals. Firstly, the uncertainty for each type of landform was described. The results were manually compared and the criteria were discussed in detail. Then, the total amount of rock glaciers and protalus ramparts mapped (n: total amount) was analyzed.

Database for each landform mapped included area, elevation, lithology, slope, aspect and potential incoming solar radiation values.

Frequency ratio and logistic regression methods were performed in order to analyze the relationship between active rock glacier occurrence and environmental variables (lithology, elevation, aspect, slope and potential incoming solar radiation). These variables were classified into categories, which were defined taking into account the rock glacier distribution over each category, and representative values were chosen for each one. 
Nine types of lithological units were identified in the area based on the Geological and Mining Service of Argentina Republic (SEGEMAR, 2008) (Table 1). Elevation, slope, aspect and potential incoming solar radiation were obtained using a digital elevation model with $12.5 \times 12.5 \mathrm{~m}$ spatial resolution provided by ALOS Palsar (Dataset: ASF DAAC 2015, ALOS 235140 PALSAR_Radiometric_Terrain_Corrected_Hi_res; Includes Material (C JAXA/METI 2007. Accessed through ASF DAAC, https://www.asf.alaska.edu 16 May 2016 DOI: 237 10.5067/JBYK3J6HFSVF). Physical parameters were calculated using the open-source Quantum GIS, GV GIS, SAGA GIS and Kosmo GIS softwares. In order to categorize these variables (elevation, slope, aspect and solar radiation), the mean, minimum and maximum rock glacier values were taken into account.

Table 1. Lithological Units.

\begin{tabular}{|l|l|l|}
\hline Symbol & \multicolumn{1}{|c|}{ Age } & \multicolumn{1}{c|}{ Description } \\
\hline PlQs & Pliocene - Quaternary & Sedimentary Deposits \\
\hline Mv & Middle to Upper Miocene & Volcanic Rocks \\
\hline Ms & Middle to Upper Miocene & Sedimentary Clastic Rocks \\
\hline OMp & Oligocene - Lower Miocene & Intrusive Porphyry and Subvolcanic Dome Rocks \\
\hline EOp & Eocene - Oligocene & Intrusive Porphyry Complex Rocks \\
\hline Jk ism & Jurassic - Lower Cretaceous & Sedimentary Clastic Rocks \\
\hline PTrg & Permian - Triassic & Intrusive Granitic Acid Rocks \\
\hline PTrv & Permian - Triassic & Volcanic, Pyroclastic and Sedimentary Alkaline Rocks \\
\hline DPig & Devonian - Lower Permian & Intrusive Basic Rocks \\
\hline
\end{tabular}

For analyzing the altitudinal distribution of the rock glaciers, the study area was divided into four main altitudinal ranges based on their elevation values (Table 2). The mean aspect units were calculated using the WGMS methodology (Paul et al., 2010). The aspect cartography was performed using the Travis et al (1975) algorithm over the ALOS PALSAR DEM (Table 3). Also, sky view factor, aspect and slope (derivatives from ALOS PALSAR DEM) were used to obtain the annual potential solar radiation cartography. In addition, the latitudinal geographic position of the study area (position of incidence of sun rays) was taken into account. In order to consider the seasonal differences that characterize subtropical areas, the measurements were calculated every 7 days in periods of 1.5 hours for a whole year by using SAGA GIS software. The measuring unit for output radiation raster was watthours per square meter $\left(\mathrm{W} \cdot \mathrm{hr} / \mathrm{m}^{2}\right)$. The chosen solar constant was $1,367 \mathrm{~W} / \mathrm{m}^{2}$, a value assigned by the World Radiation Reference Centre (WRRC) proposed by the WMO (World Meteorological Organization).

Table 2. Elevation units.

\begin{tabular}{|c|c|c|c|c|}
\hline \multirow{2}{*}{\multicolumn{2}{|c|}{ Elevation Units }} & \multicolumn{2}{|c|}{ Elevation (m.a.s.l.) } & \multirow{2}{*}{ Area $\left(\mathrm{Km}^{2}\right)$} \\
\hline & & Min. & Max. & \\
\hline \multicolumn{2}{|c|}{ High Periglacial Environment } & 4225 & 4750 & 17.23 \\
\hline \multirow{3}{*}{$\begin{array}{l}\text { Current } \\
\text { Periglacial } \\
\text { Environment }\end{array}$} & Upper & 4047 & 4225 & 36.26 \\
\hline & Middle & 3868 & 4047 & 70.12 \\
\hline & Lower & 3690 & 3868 & 104.3 \\
\hline \multicolumn{2}{|c|}{ Unstable Periglacial Environment } & 3300 & 3690 & 283.58 \\
\hline \multicolumn{2}{|c|}{ Seasonal Frost } & 2940 & 3300 & 118.45 \\
\hline
\end{tabular}


Table 3. Aspect units.

\begin{tabular}{|c|c|c|}
\hline Aspect units & \multicolumn{2}{|c|}{ Degree } \\
\hline $\mathrm{N}$ & 337.5 & 22.5 \\
\hline $\mathrm{NE}$ & 22.5 & 67.5 \\
\hline $\mathrm{E}$ & 67.5 & 112.5 \\
\hline $\mathrm{SE}$ & 112.5 & 157.5 \\
\hline $\mathrm{S}$ & 157.5 & 202.5 \\
\hline $\mathrm{SW}$ & 202.5 & 247.5 \\
\hline $\mathrm{W}$ & 247.5 & 292.5 \\
\hline $\mathrm{NW}$ & 292.5 & 337.5 \\
\hline
\end{tabular}

Frequency ratio analyzes the relationship between the occurrences of a landform (in this case rock glaciers) and the different categories of the environmental variables studied (Bonham-Carter, 1994; Esper Angillieri, 2010). This method takes the number of pixels with rock glacier occurrence over a determinate category for each variable as input data, and then considers the percentage of the total number of pixels with respect to the complete study area (Eq. 1).

$$
F_{r}=\left(N_{i} / N\right) / S_{i} / S
$$

Therefore, the frequency ratio $\left(F_{r}\right)$ can be calculated through the following Eq. (1). Where $S$ is the total number of pixels; $N$ is the number of pixels with rock glacier occurrence; $S_{i}$ is the number of pixels, being $i$ the factor or variable; and $\mathrm{N}_{\mathrm{i}}$ is the number of pixels in which the rock glaciers occurred for the $i$-attribute or factor. If $F_{r}$ is greater than 1 , it means a higher correlation. A value smaller than 1 means a lower correlation.

Logistic regression estimates the probability of rock glacier existence based on independent variables or predictors (Hosmer and Lemeshow, 1989; Atkinson et al., 1998). It is a multivariate regression model where the dependent variable is categorical, this paper covers the case of a binary dependent variable: absence and presence of rock glaciers (values 0 and 1). The predictor variables used were lithology, elevation, slope, aspect and potential incoming solar radiation. The lithological and aspect units were treated as categorical variables, while slope, elevation, and solar radiation were considered as continuous variables. A bilateral and Pearson correlation coefficient was applied to verify the existence of correlation between variables and to evaluate their independence.

For logistic regression analysis, the number of points representing areas with rock glacier occurrence or non-occurrence should be the same (Ayalew and Yamagishi, 2005). In the study area, 1000 points represent the active rock glacier presence. Therefore, 1000 points without rock glacier occurrence were randomly selected for logistic regression; while $\mathrm{N}$ is the total number of analyzed points $=2000$. This data is used to incorporate predictor variables, thus allowing to estimate the probability of rock glacier occurrence from the presence of some category of each variable.

Also, a multicollinearity checking was performed in order to assess the correlation between independent variables (Hosmer and Lemeshow, 1989). Multicollinearity is a statistical situation in which two or more predictor variables are highly correlated, meaning that one can be linearly predicted from the others with a non-trivial degree of accuracy. Tolerance (TOL) and the variance inflation factor (VIF) are two important indexes that are widely used for multicollinearity checking. According to Menard (1995), a TOL value of less than 0.2 is one indicator for multicollinearity, and serious multicollinearity occurs between independent variables when the TOL values are smaller than 0.1 . The VIF is calculated by $1 /$ tolerance. If the VIF value exceeds 10 , it is often regarded as indicating multicollinearity. 


\section{Results}

The study area, which covers $630 \mathrm{~km}^{2}$, is characterized by a wide development of periglacial environment. The total number of rock glaciers and protalus ramparts inventoried is 405 with an accuracy of \pm 8.2 (Fig. 2, Table 4).

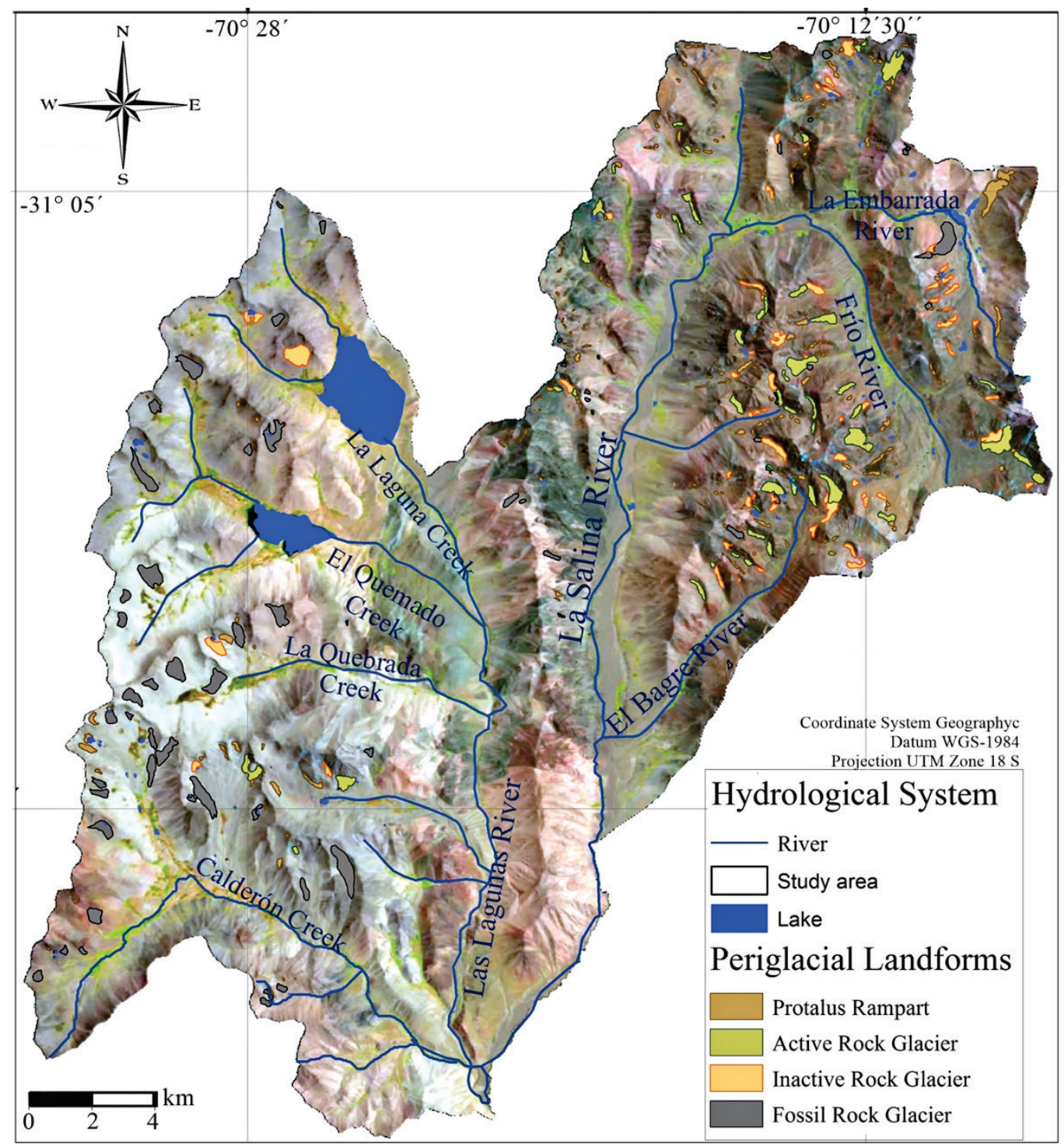

Figure 2. Rock glacier and protalus rampart inventory.

Table 4. Inventory uncertainty assessment.

\begin{tabular}{|l|c|c|c|c|c|c|}
\hline \multicolumn{1}{|c|}{ Type of landforms } & $\mathbf{n}_{\mathbf{a}}{ }^{*}$ & $\mathbf{n}_{\mathbf{b}}{ }^{* * *}$ & $\mathbf{n}_{\mathbf{m}}{ }^{* * *}$ & variance & Stand. dev. & According number \\
\hline Active rock glacier & 53 & 49 & 51 & 4 & 2 & $49+/-2$ \\
\hline Inactive rock glacier & 62 & 60 & 61 & 1 & 1 & $61+/-1$ \\
\hline Fossil rock glacier & 66 & 60 & 63 & 9 & 3 & $64+/-3$ \\
\hline Protalus rampart & 234 & 229 & 231.5 & 6.25 & 2,5 & $231+/-2,5$ \\
\hline Total of landforms & 415 & 398 & 406.5 & 67.24 & 8.2 & $405+/-8.2$ \\
\hline
\end{tabular}

${ }^{*} \mathrm{Na}$ : Amount of landforms identified by Person A.

${ }^{* *} \mathrm{Nb}$ : Amount of landforms identified by Person B.

${ }^{* * *} \mathrm{Nm}$ : average of both values. 
A number of 231 protalus ramparts and 174 rock glaciers have been identified -49 considered active rock glaciers. Field studies were performed over $80 \%$ of the total inventory (Fig. 3).

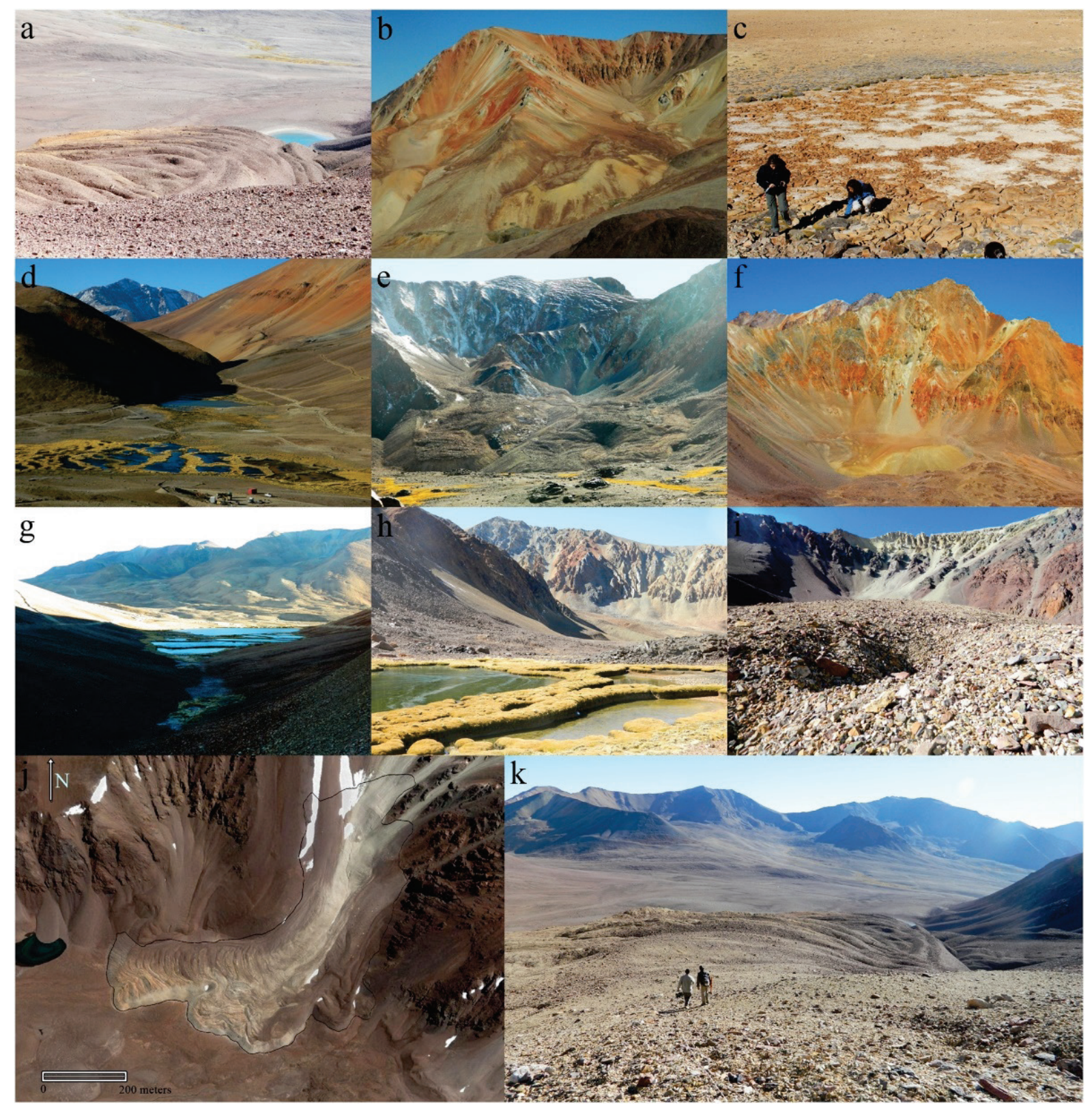

Figure 3. Periglacial landforms identified in the field. a) Furrows and ridges on an active rock glacier (geographic coordinates: $31^{\circ} 9.75^{\prime} \mathrm{S}$ and $70^{\circ} 12.8^{\prime} \mathrm{W}$ ). b) Inactive rock glacier (geographic coordinates: $31^{\circ} 12^{\prime} \mathrm{S}$ and $70^{\circ} 14.5^{\prime} \mathrm{W}$ ). c) Patterned ground (geographic coordinates: $31^{\circ} 3^{\prime} 50^{\prime \prime S}$ and $70^{\circ} 14^{\prime} 10^{\prime \prime} \mathrm{W}$ ). d) Vegas or Andean wetlands associated to lagoon systems (geographic coordinates: $31^{\circ} 6^{\prime} S$ and $70^{\circ} 13^{\prime} 40^{\prime \prime} \mathrm{W}$ ). e) Los Patos Norte active rock glacier (geographic coordinates: $31^{\circ} 3.1^{\prime} \mathrm{S}$ and $70^{\circ} 15^{\prime} \mathrm{W}$ ). $\mathrm{f}$ ) Active rock glacier (geographic coordinates: $31^{\circ} 10^{\prime}$ and $70^{\circ} 12.1^{\prime} \mathrm{W}$ ). g) Vegas or Andean wetlands associated to water springs and lagoon systems (geographic coordinates: $31^{\circ} 5^{\prime} 25^{\prime \prime}$ S and 70 $73^{\circ} 11^{\prime \prime} \mathrm{W}$ ). h) Vegas or Andean wetlands associated to water springs and lagoon systems (geographic coordinates: $31^{\circ} 31^{\circ} 6^{\prime} 40^{\prime \prime S}$ and $70^{\circ} 13^{\prime} 7^{\prime \prime} \mathrm{W}$ ). i) Thermokarst on Amarillo active rock glacier surface (geographic coordinates: $31^{\circ} 9^{\prime} 45^{\prime \prime} \mathrm{S}$ and $70^{\circ} 12^{\prime} 57^{\prime \prime} \mathrm{W}$ ). j) Amarillo active rock glacier mapping (geographic coordinates: $31^{\circ} 9.75^{\prime} \mathrm{S}$ and $70^{\circ} 12.8^{\prime} \mathrm{W}$ ). $\mathrm{k}$ ) Furrows and ridges on Amarillo active rock glacier surface. two persons as scale. 
The altitudinal distribution of the periglacial landforms identified varies between $2940 \mathrm{~m}$ a.s.l. and $4750 \mathrm{~m}$ a.s.1. The total elevation range was fragmented into 4 altitudinal units, based on minimum and maximum elevation of intact rock glaciers (Table 2 and Fig. 4 and 5) and, in turn, the third unit was subdivided into three classes.

The first unit (between 2940 and $3300 \mathrm{~m}$ a.s.1.) was considered a seasonal frost unit because no periglacial landforms were identified under it, only fossil landforms (Fig. 5c). So, it is probable that periglacial phenomena are mainly limited to seasonal freezing and thawing. The second unit comprises the area between 3300 and $3690 \mathrm{~m}$ a.s.l. (lower inactive and active rock glacier elevation); which is considered an unstable periglacial environment unit, since there are only inactive rock glaciers (Fig. 5b). The third unit includes areas comprehended between the lower and upper active rock glacier elevations (Fig. 5a). As mentioned above, this unit was subdivided into three intervals corresponding to the lower, middle and upper current periglacial environments (3690-3868, 3868-4047 and 4047-4225 m a.s.1.), considering the area below $3300 \mathrm{~m}$ a.s.l. the lower intact rock glacier altitude. The fourth and highest unit includes areas with higher elevations than $4225 \mathrm{~m}$ a.s.l., generally mountain peaks, where landforms lie on the highest slopes (Fig. 4 and 5).

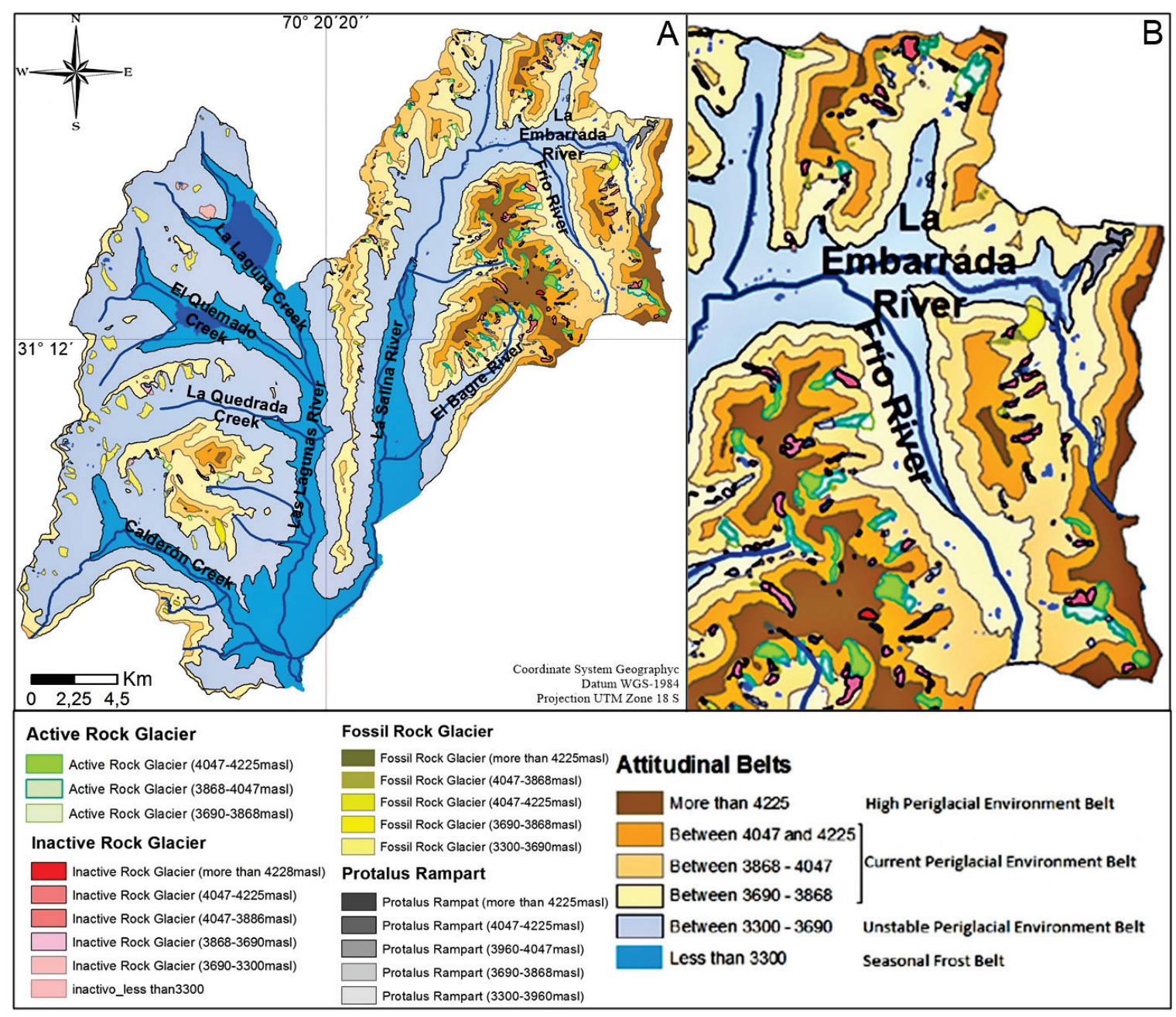

Figure 4. Rock glacier and protalus rampart distribution over the six altitudinal units. A) Regional map. B) Detailed view of the area with the highest density of periglacial landforms. 
Forte et al.

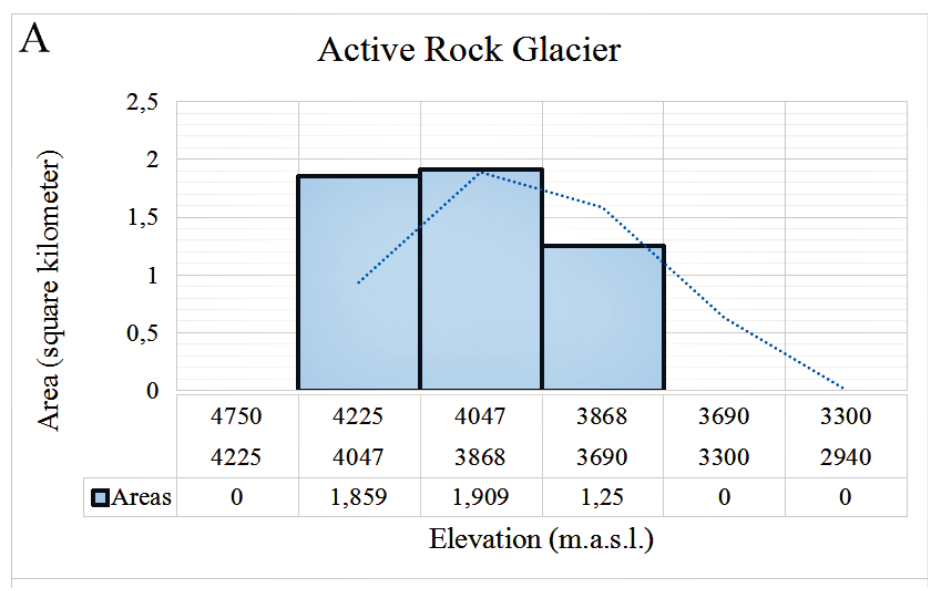

$\mathrm{B}$

Inactive Rock Glacier

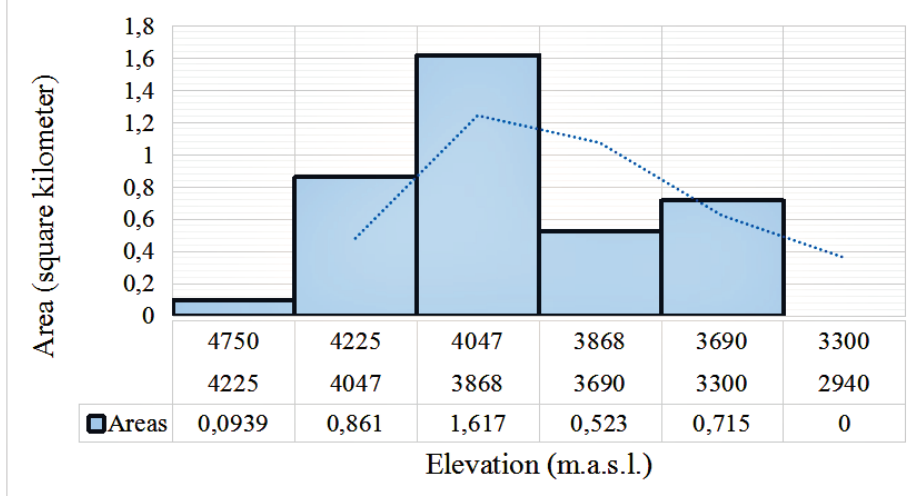

C Fossil Rock Glacier

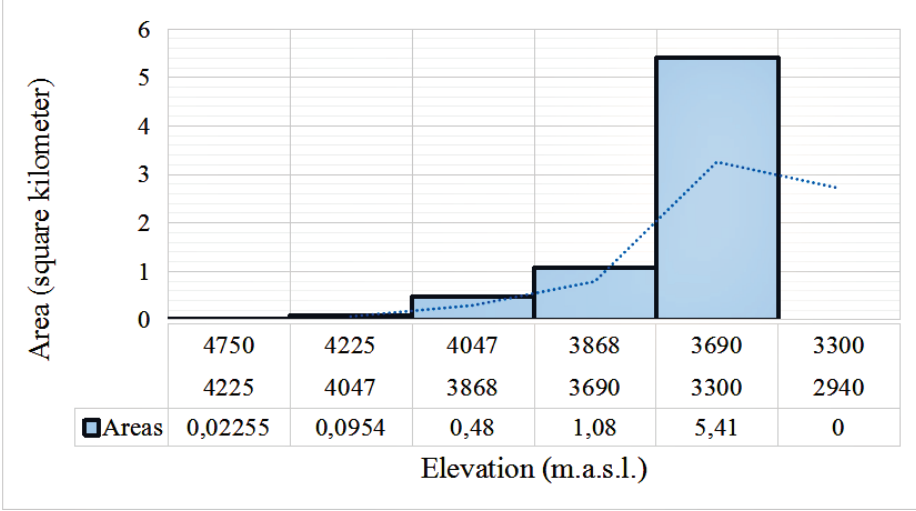

$\mathrm{D}$

Protalus Rampart

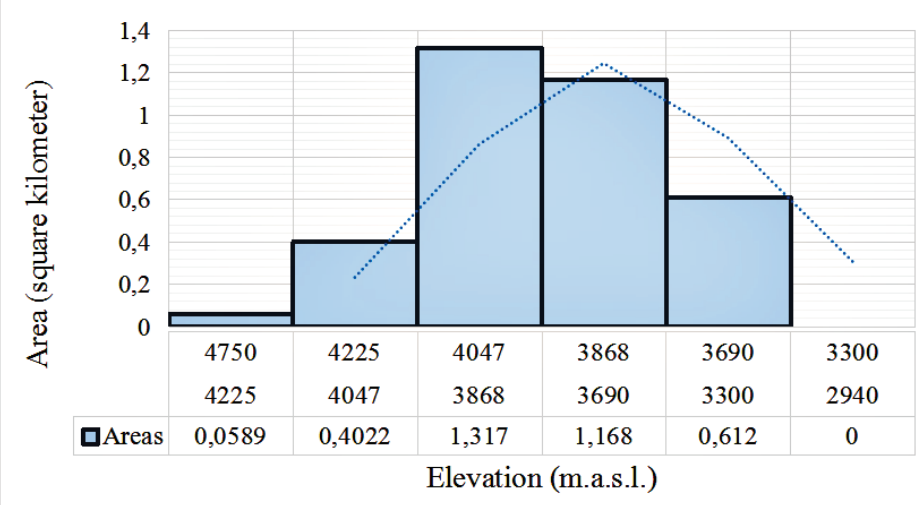

Figure 5. Hypsometry of the studied periglacial landforms. A) Active rock glaciers. B) Inactive rock glaciers. C) Fossil rock glaciers. D) Protalus rampart. 
The spatial distribution of rock glaciers and protalus ramparts over the nine lithological units shows that rock glaciers are usually made up of volcanic, pyroclastic and sedimentary alkaline rocks (PTrv) and, to a lesser extent, by intrusive granitic rocks (PTrg); both lithologies are Permian-Triassic rocks with a significant degree of Cenozoic hydrothermal alteration (Fig. 6 and 7). Also, active rock glaciers trend to appear over areas with Middle to Upper Miocene volcanic rock outcrops (Mv). While inactive rock glaciers are developed more frequently on intrusive porphyric and subvolcanic rocks from the Oligocene-Lower Miocene (OMp) and Eocene-Oligocene (EOp) periods.

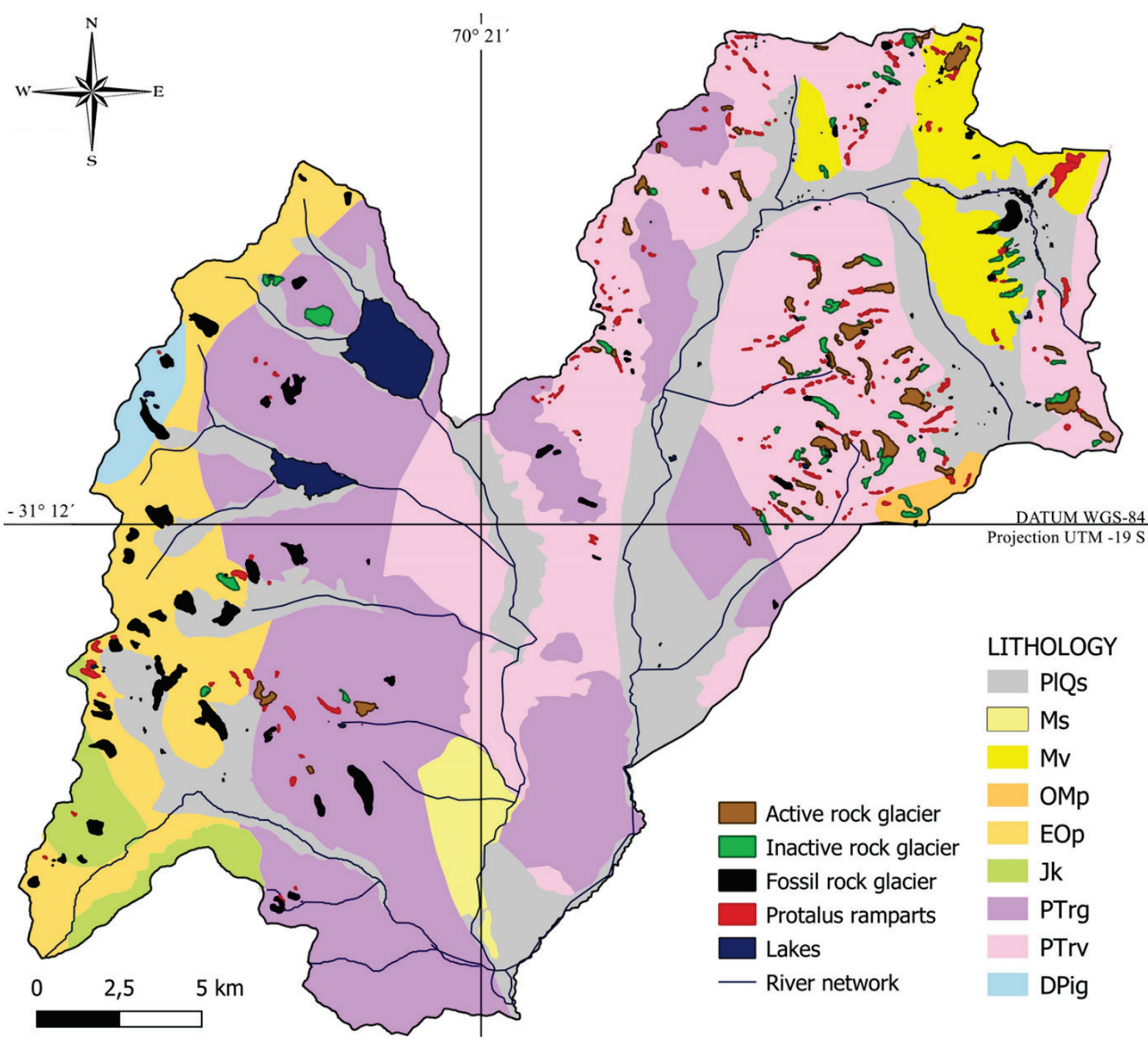

Figure 6. Rock glacier and protalus rampart distribution over the nine lithological units based on SEGEMAR geological map (2008). PlQs: Pliocene-Quaternary sedimentary deposits. Mv: Middle to upper Miocene volcanic rocks. Ms: middle to upper Miocene sedimentary clastic rocks. OMp: Oligocene-lower Miocene intrusive porphyry and subvolcanic rocks. EOp: Eocene-Oligocene intrusive porphyry complex rocks. Jk ism: Jurassic-lower Cretaceous sedimentary clastic rocks. PTrg. Permian-Triassic intrusive granitic acid rocks. PTrv: Permian-Triassic volcanic, pyroclastic and sedimentary alkaline rocks. DPig: Devonian-lower Permian intrusive basic rocks 
Forte et al.
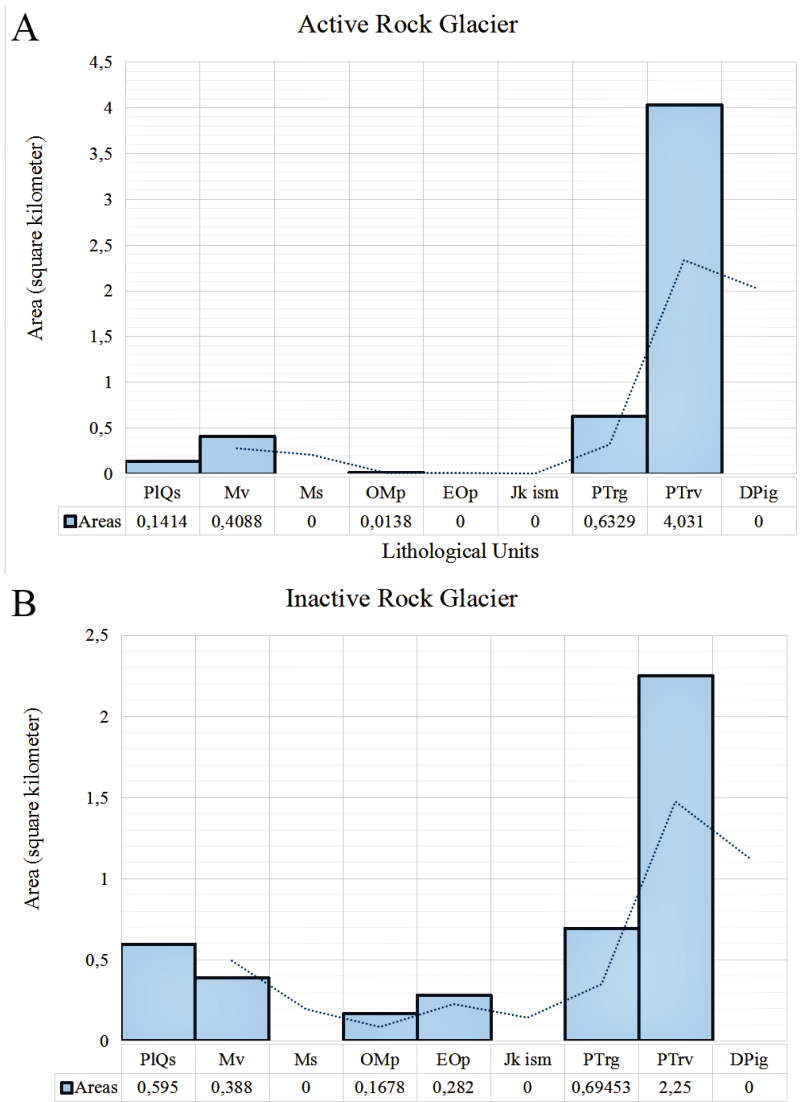

\begin{tabular}{l|l|l|l|l|r|r|r|r|r|} 
口Areas & 0,595 & 0,388 & 0 & 0,1678 & 0,282 & 0 & 0,69453 & 2,25 & 0
\end{tabular}
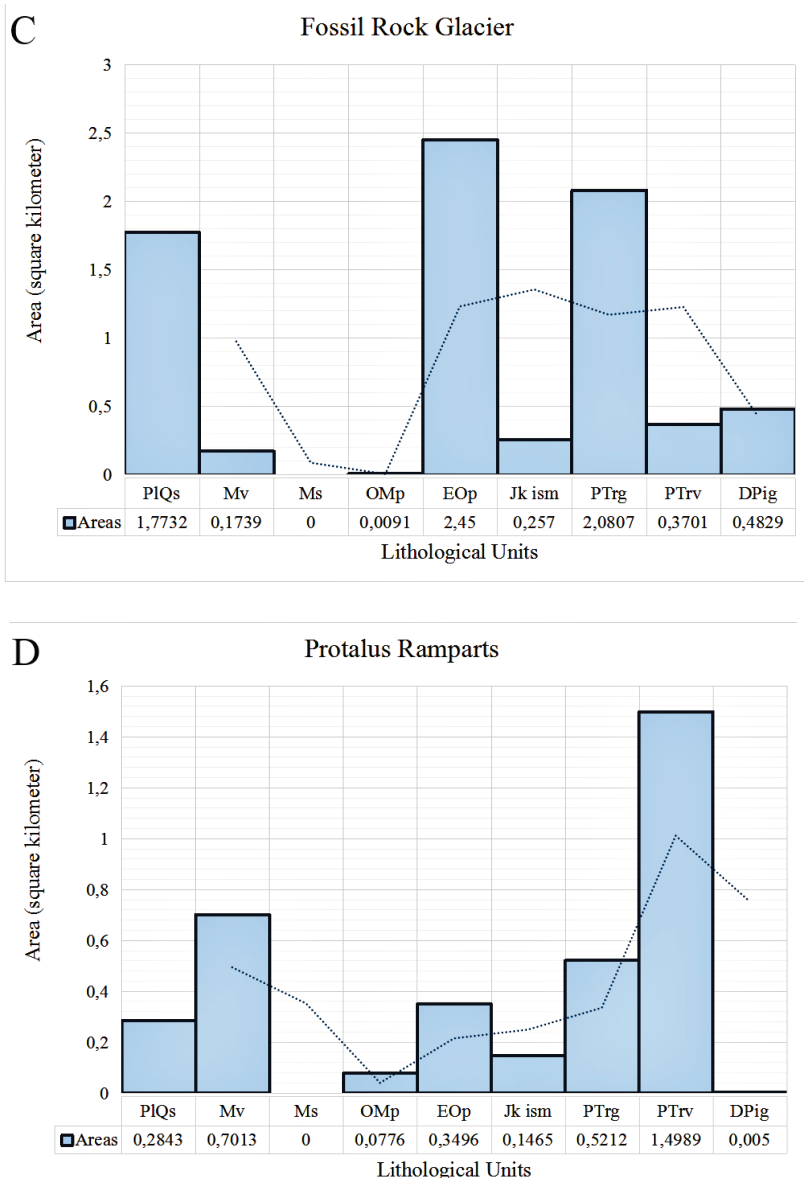

Figure 7. Area occupied. over lithological units. by: A) Active rock glaciers. B) Inactive rock glaciers. C) Fossil rock glaciers. D) Protalus rampart. 
Slope has been classified in 4 units with intervals: $0-11 \% ; 11-20 \% ; 20-35 \%$ and $35-75 \%$. The mean slope of active rock glaciers is between $11.2 \%$ and $28.5 \%$ with an average of $18.9 \%$. The mean slope of inactive rock glaciers has minimum values of $8.5 \%$, maximum values of $26 \%$ and averages of $18.5 \%$. Lastly, the mean slope of fossil rock glaciers has minimum values of $3.9 \%$, maximum values of $31.3 \%$ and averages of $12.7 \%$; and the mean slope of protalus ramparts has minimum values of $4.5 \%$, maximum values of $48.8 \%$ and averages of $4.5 \%$. This shows that a very high slope (greater than $35 \%$ ) is not related to rock glacier occurrence (Fig. 8 and 9).

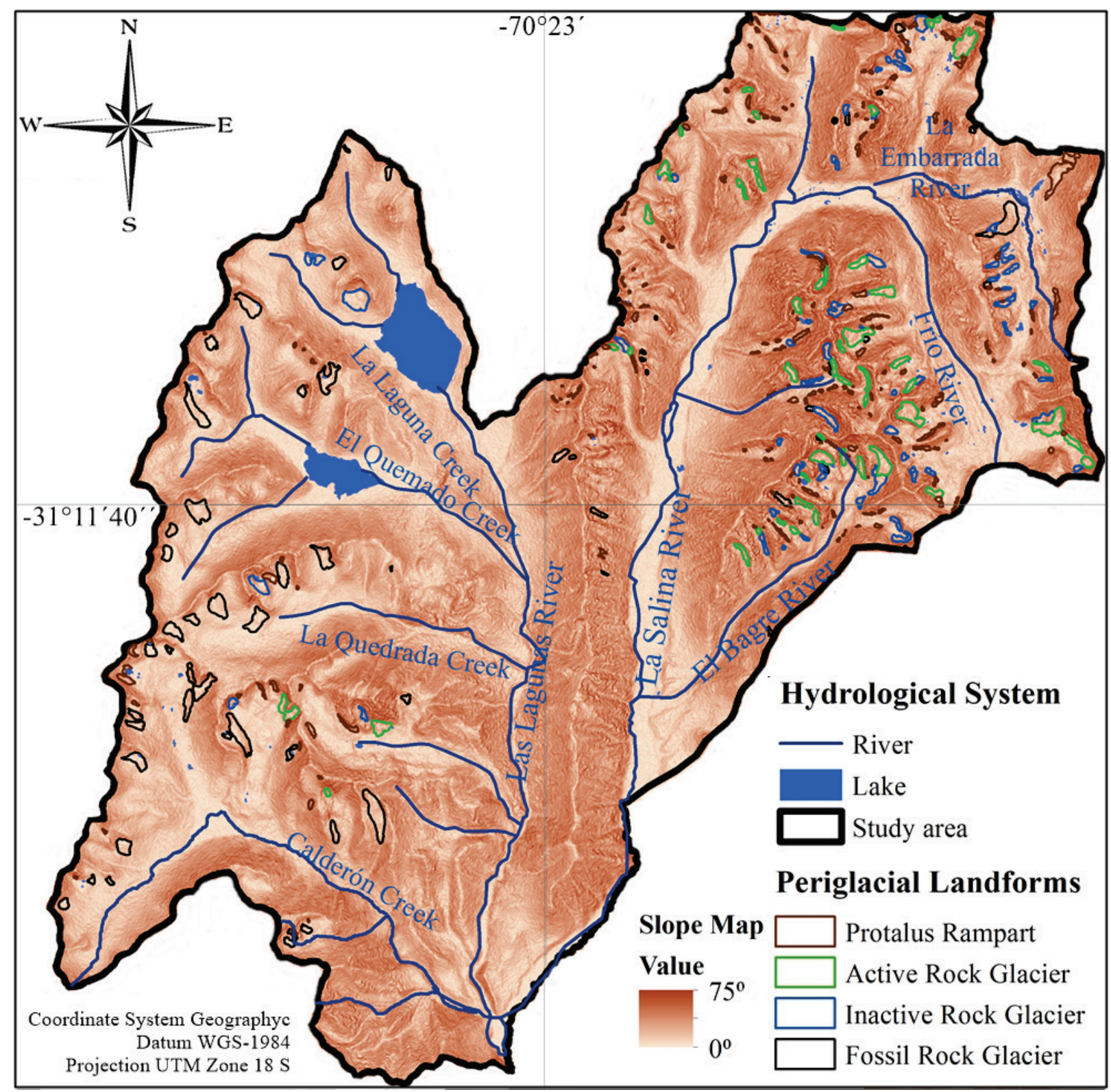

Figure 8. Rock glacier and protalus rampart distribution over the four slope units. 
Forte et al.
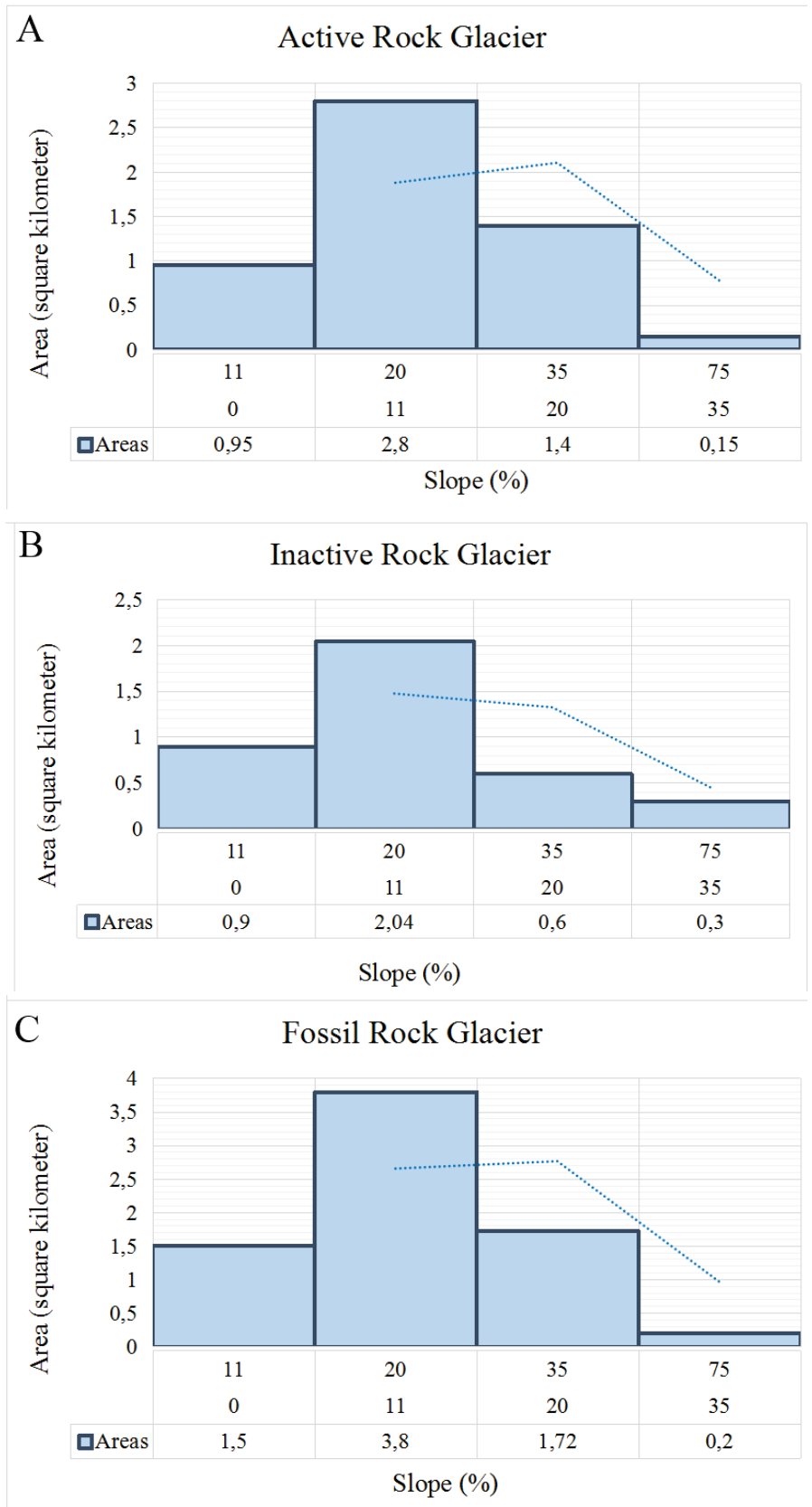

D Protalus Rampart

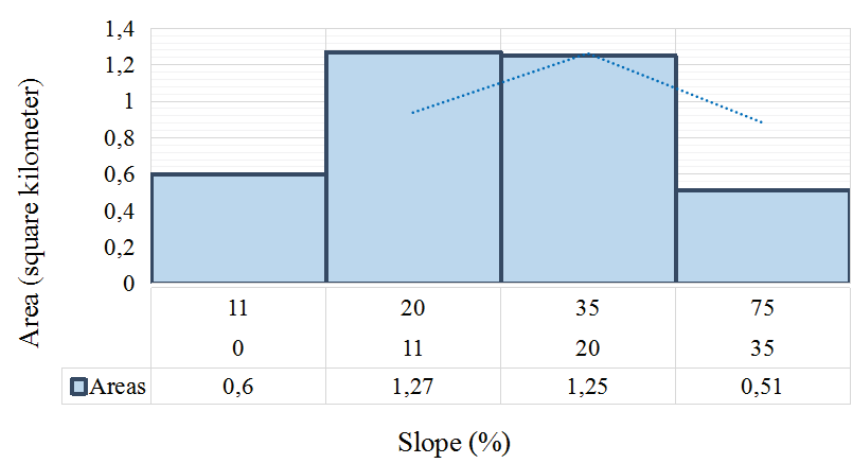

Figure 9. Area occupied by periglacial landforms over slope units. A) Active rock glaciers. B) Inactive rock glaciers. C) Fossil rock glaciers. D) Protalus rampart. 
The aspect analysis shows that active rock glaciers are generally south and south-west oriented. Some are oriented to the east due to the Bagres range layout which accompanies the rock glacier development in said direction. North-faces contain almost no active rock glaciers. In addition, inactive rock glaciers are predominant on the south-face of mountains and, to a lesser extent, on the east and west faces, as shown mainly on the Bagres and La Totora ranges (Fig. 10). While the aspect of fossil rock glaciers has a clear trend toward the southeast, protalus ramparts show a highly diverse characterization. This type of feature is practically present in all directions, though occurrences are most common on west-facing slopes and are less frequent on north-faces (Fig. 10 and 11).

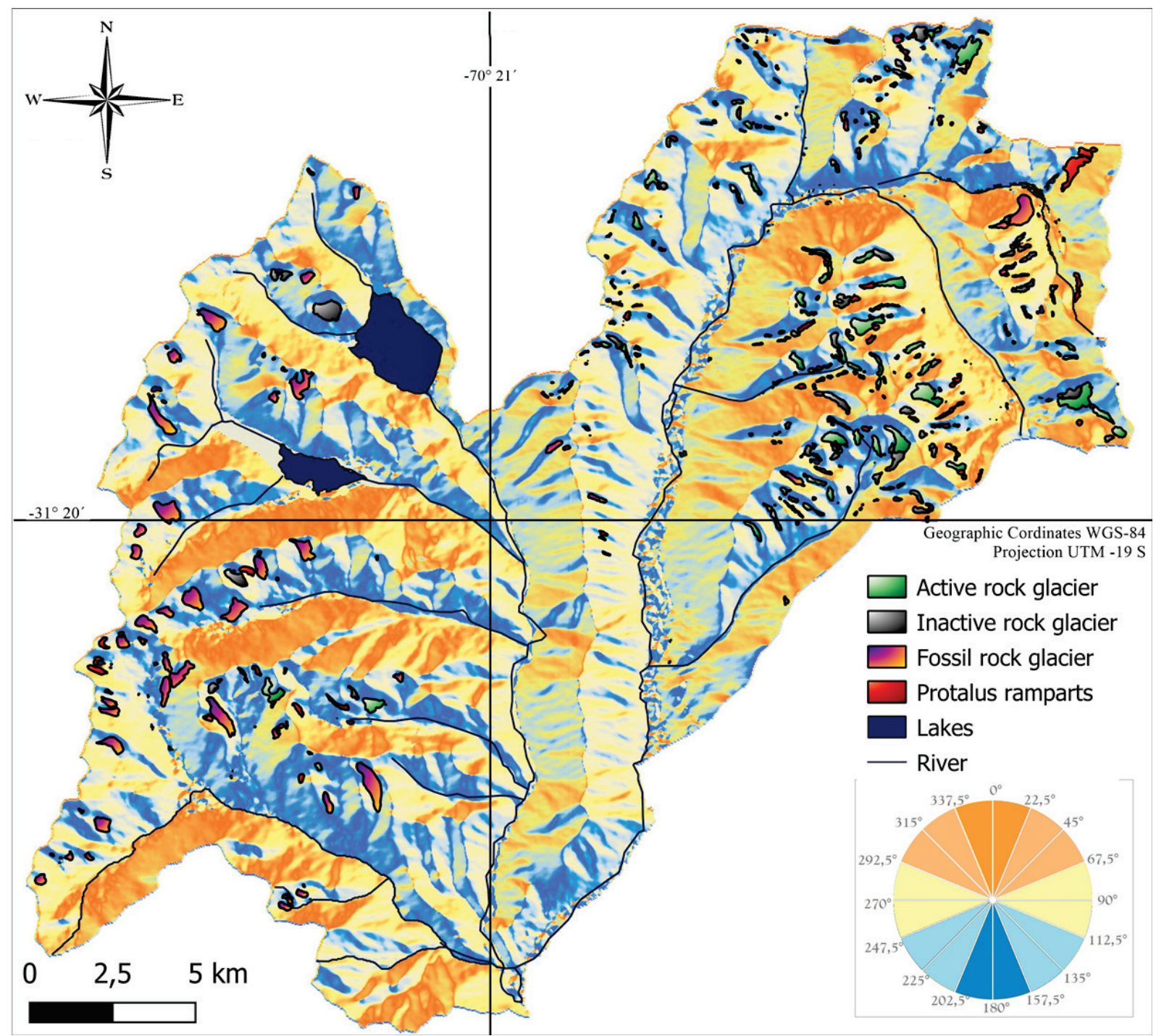

Figure 10. Rock glacier and protalus rampart distribution over the eight aspect units. Red and orange represent the warm north faces; yellow represents the west and east faces; while blue and light green show the cold south faces. 
A

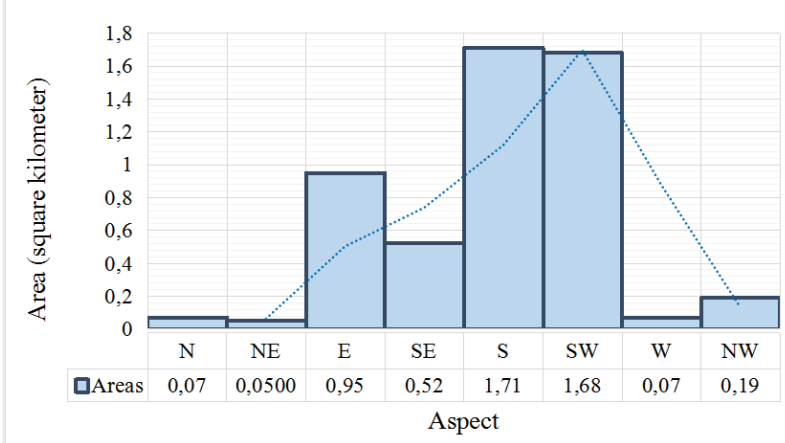

C

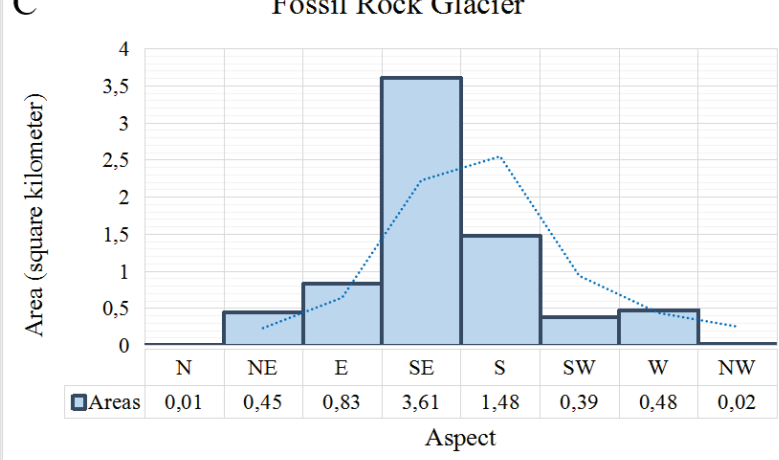

B

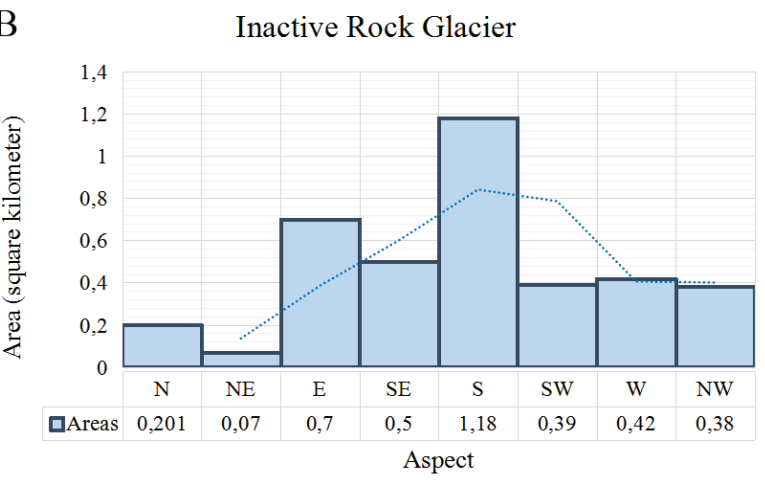

D

Protalus Rampart

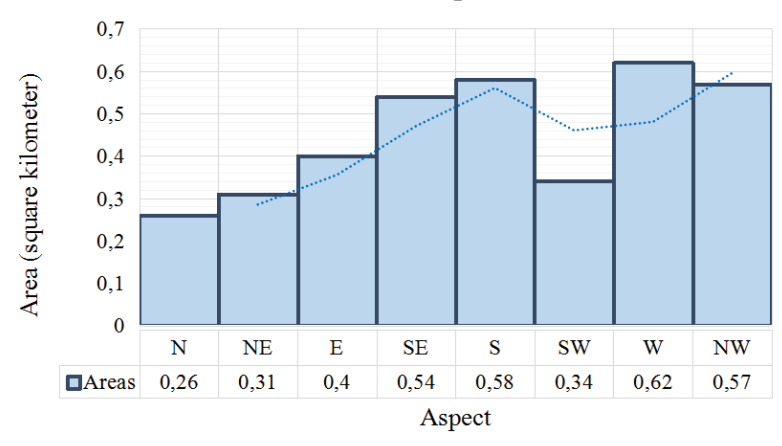

E ACTIVE ROCK GLACIERS

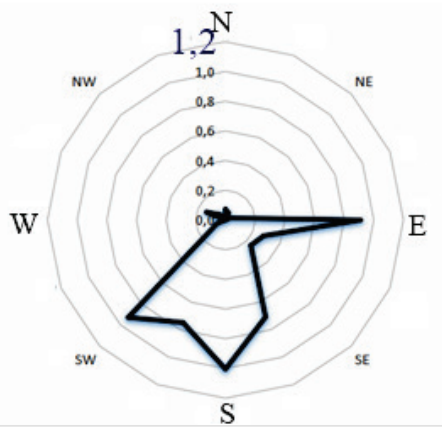

$\mathrm{G}^{\text {PSEUDO-RELICT ROCK GLACIERS }}$

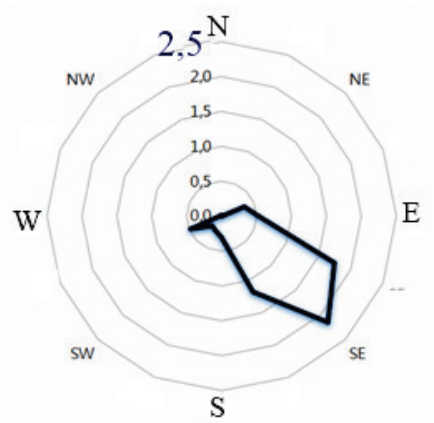

\section{F INACTIVE ROCK GLACIERS}

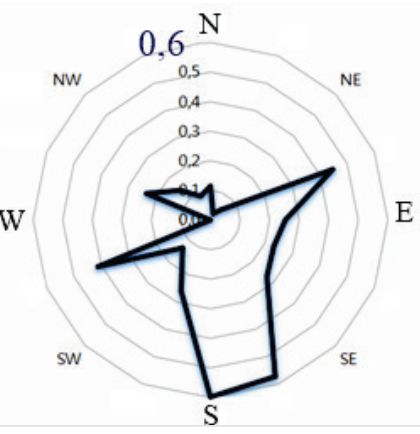

\section{PROTALUS RAMPART}

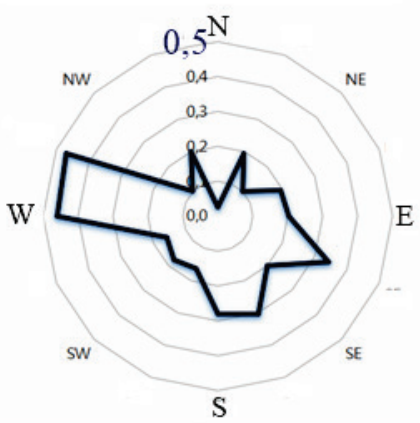

Figure 11. Periglacial landforms over the eight aspect units. A) Area occupied by active rock glaciers over each aspect unit. B) Area occupied by inactive rock glaciers over each aspect unit. C) Area occupied by fossil rock glaciers over each aspect unit. D) Area occupied by protalus ramparts over each aspect unit. E) Amount of active rock glaciers with mean aspect over the same unit. F) Amount of inactive rock glaciers with mean aspect over the same unit. G) Amount of fossil rock glaciers with mean aspect over the same unit. H) Amount of protalus ramparts with mean aspect over the same unit. 
Potential direct annual solar radiation shows a minimum of $660 \mathrm{Wh} / \mathrm{m}^{2}$ and a maximum of 2600 $\mathrm{KWh} / \mathrm{m}^{2}$ for the study area (Fig. 12). This variable was divided into four units to analyze the rock glacier and protalus rampart distribution (Fig. 13). Values for active rock glaciers vary between 857 and 2322 $\mathrm{KWh} / \mathrm{m}^{2}$ and the average values for rock glaciers and protalus ramparts are $1800-1900 \mathrm{KWh} / \mathrm{m}^{2}$. The potential incoming solar radiation in the valleys is irregular and it usually shows low values in southfacing slopes, lower lying terrain and shade-casted areas; which allows rock glaciers to develop at lower elevations. However, the potential incoming solar radiation values for intact rock glaciers are lower than those for fossil rock glaciers and protalus ramparts (Fig. 13). On active rock glaciers, the radiation readings show a bit less solar exposure. Over south-facing slopes, there is a minor heliophany which decreases the solar radiation and allows rock glaciers to develop or to be preserved.

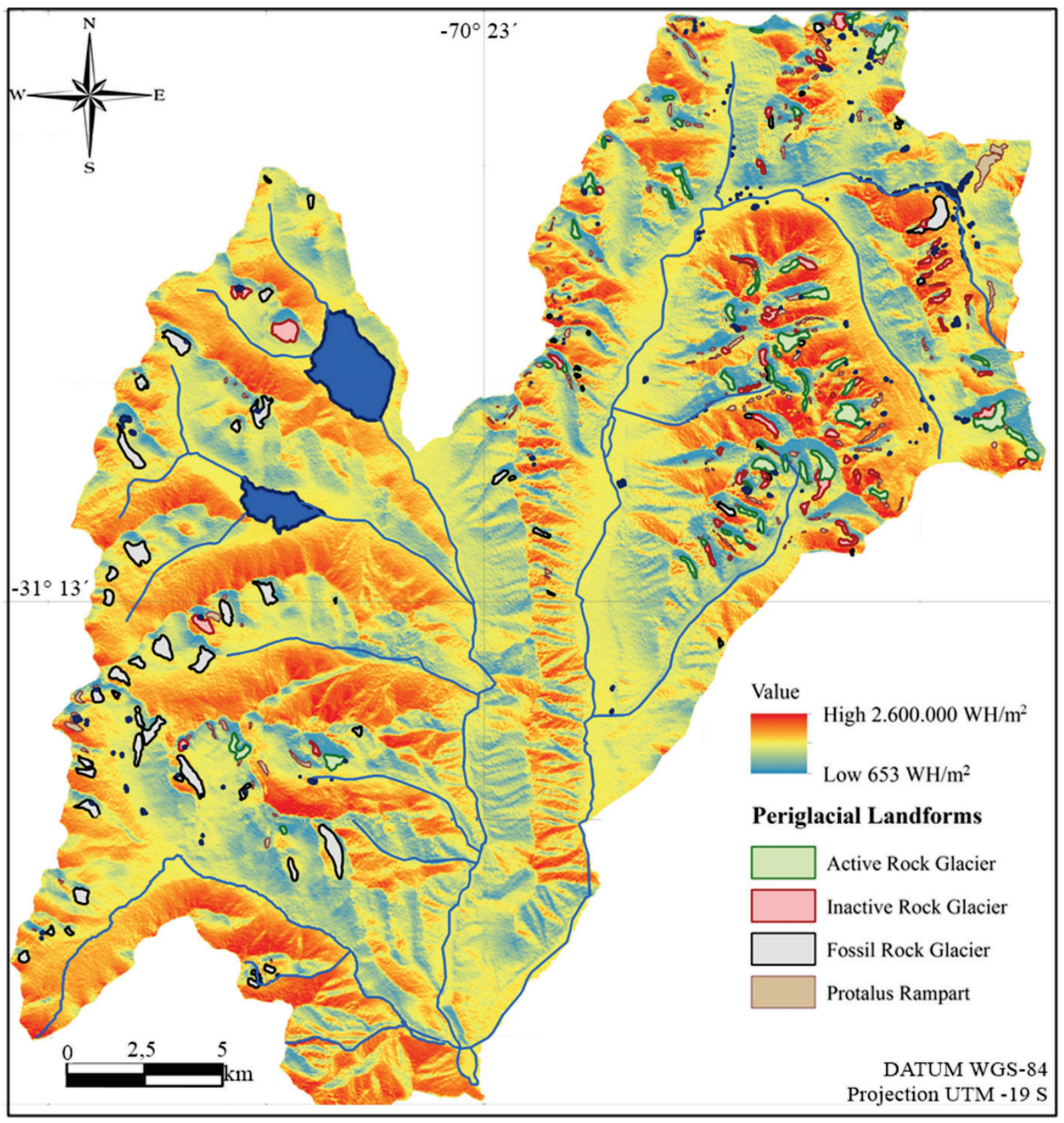

Figure 12. Rock glacier and protalus rampart over the four solar radiation units. 

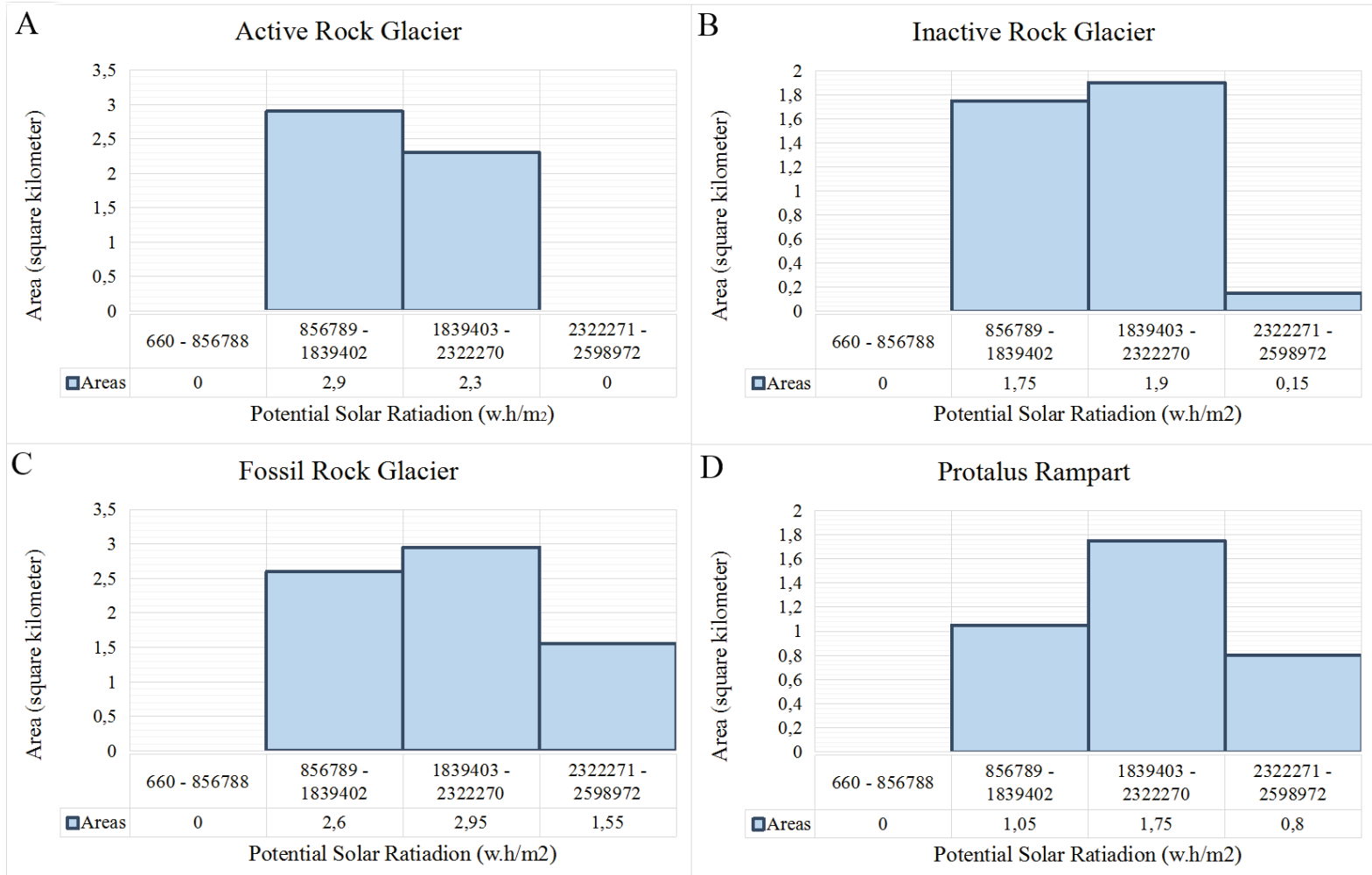

Figure 13. Area occupied over solar radiation units by: A) Active rock glaciers. B) Inactive rock glaciers. C) Fossil rock glaciers. D) Protalus rampart.

The frequency ratio (Fr) analysis over active rock glaciers was calculated for each environmental variable. Elevation is shown as the most important parameter, evidencing the highest frequency ratio value of 6.2 for elevations above $4048 \mathrm{~m}$ a.s.1.

The influence of lithology is the second most important parameter with $\mathrm{Fr}=2.5$ for PermianTriassic volcanic, pyroclastic and sedimentary rocks (PTrv), which are mainly compounded by basalt, andesite, dacite and rhyolits rocks.

Aspect is the third most relevant parameter for active rock glacier occurrence, with a maximum value of frequency ratio on the south-faces $(\mathrm{Fr}=2.66)$.

The remaining parameters -potential incoming solar radiation and slope- show a lower influence. However, slopes between 11 and $20 \%$ and values of radiation between 856,789 to 2,322,270 $\mathrm{Wh} / \mathrm{m}^{2}$ display frequency ratio values greater than 1 (Table 5).

The logistic regression coefficients (RL) for the distribution of active rock glaciers are also shown in Table 5 . The system designed is valid, its shows that an $89.1 \%$ of the predicted pixels are being used correctly $(90.9 \%$ of the active rock glacier pixels and $87.3 \%$ of the areas with non-rock glacier pixels). Collinearity correlation between predictor variables express independently in the regression model, so can predict the value of the dependent variable (Table 6). 
Table 5. Ratio frequency and logistic regression analyses.

\begin{tabular}{|c|c|c|c|c|c|c|c|}
\hline Factor & Class & $\begin{array}{c}\text { Pixels } \\
\text { showing } \\
\text { active rock } \\
\text { glaciers }^{\mathrm{a}} \\
\end{array}$ & $\begin{array}{l}\text { \% of pixels } \\
\text { showing } \\
\text { rock } \\
\text { glaciers }^{b} \\
\end{array}$ & $\begin{array}{l}\text { Pixels in } \\
\text { domain }^{c}\end{array}$ & $\begin{array}{c}\text { Pixels } \\
\%^{d}\end{array}$ & $\begin{array}{c}\text { Frequenc } \\
\text { y ratio }\end{array}$ & $\begin{array}{c}\text { Logistic } \\
\underset{\text { RR }}{\text { Regression }}\end{array}$ \\
\hline \multirow{6}{*}{$\begin{array}{c}\text { Elevation } \\
\text { (m.a.s.l.) }\end{array}$} & $2950-3299$ & 0 & 0.000 & 723601 & 18.104 & 0.000 & -19.966 \\
\hline & $3300-3689$ & 0 & 0.000 & 1252217 & 31.330 & 0.000 & -0.748 \\
\hline & $3690-3867$ & 9057 & 27.188 & 1178607 & 29.488 & 0.922 & 1.441 \\
\hline & $3868-4047$ & 12186 & 36.580 & 427470 & 10.695 & 3.420 & 1.993 \\
\hline & $4048-4225$ & 12070 & 36.232 & 232191 & 5.809 & 6.237 & 2.328 \\
\hline & $4226-4763$ & 0 & 0.000 & 182801 & 4.574 & 0.000 & 1 \\
\hline \multirow{8}{*}{$\begin{array}{c}\text { Aspect } \\
\text { (degree) }\end{array}$} & $338-22$ & 703 & 2.110 & 504867 & 12.632 & 0.167 & 17.989 \\
\hline & $23-67$ & 1250 & 3.752 & 497005 & 12.435 & 0.302 & 18.084 \\
\hline & $68-112$ & 3819 & 11.464 & 603825 & 15.107 & 0.759 & 18.545 \\
\hline & $113-157$ & 6286 & 18.870 & 544826 & 13.631 & 1.384 & 20.54 \\
\hline & $158-202$ & 9124 & 27.389 & 411352 & 10.292 & 2.661 & 21.507 \\
\hline & $203-247$ & 8039 & 24.132 & 494739 & 12.378 & 1.950 & 21.117 \\
\hline & $248-293$ & 2953 & 8.864 & 545267 & 13.642 & 0.650 & 19.284 \\
\hline & 294-337 & 1139 & 3.419 & 395006 & 9.883 & 0.346 & 18.225 \\
\hline \multirow{4}{*}{$\begin{array}{c}\text { Slope } \\
\text { (percentage) }\end{array}$} & $0-10$ & 6109 & 18.338 & 1072973 & 26.845 & 0.683 & -0.423 \\
\hline & 11-19 & 17930 & 53.823 & 1219425 & 30.509 & 1.764 & 1.33 \\
\hline & $20-35$ & 8525 & 25.591 & 1495870 & 37.426 & 0.684 & 1.585 \\
\hline & $35-75$ & 749 & 2.248 & 208619 & 5.220 & 0.431 & 1 \\
\hline \multirow{9}{*}{ Lithology } & $\begin{array}{l}\text { Pliocene-Quaternary } \\
\text { Sedimentary deposits }\end{array}$ & 900 & 2.702 & 855951 & 21.415 & 0.126 & -1.534 \\
\hline & $\begin{array}{c}\text { Middle to Upper } \\
\text { Miocene-Volcanic } \\
\text { Rocks }\end{array}$ & 2570 & 7.715 & 192497 & 4.816 & 1.602 & -0.995 \\
\hline & $\begin{array}{c}\text { Middle to Upper } \\
\text { Miocene- Sedimentary } \\
\text { rocks } \\
\end{array}$ & 0 & 0.000 & 73069 & 1.828 & 0.000 & -19.516 \\
\hline & $\begin{array}{c}\text { Oligocene to Lower } \\
\text { Miocene-Intrusive } \\
\text { Rocks }\end{array}$ & 84 & 0.252 & 22802 & 0.570 & 0.442 & -1.385 \\
\hline & $\begin{array}{l}\text { Eocene to Oligocene- } \\
\text { Intrusive Rocks }\end{array}$ & 0 & 0.000 & 374766 & 9.376 & 0.000 & -20.213 \\
\hline & $\begin{array}{c}\text { Jurassic to Lower } \\
\text { Cretaceous- } \\
\text { Sedimentary rocks } \\
\end{array}$ & 0 & 0.000 & 90136 & 2.255 & 0.000 & -19.28 \\
\hline & $\begin{array}{l}\text { Permian to Triassic- } \\
\text { Intrusive rocks }\end{array}$ & 4050 & 12.157 & 1227578 & 30.713 & 0.396 & -1.001 \\
\hline & $\begin{array}{l}\text { Permian to Triassic- } \\
\text { Vulcano-sedimentary } \\
\text { rocks }\end{array}$ & 24909 & 74.773 & 1117440 & 27.958 & 2.674 & 1 \\
\hline & $\begin{array}{c}\text { Devonian to Lower } \\
\text { Permia Intrusive rocks }\end{array}$ & 0 & 0.000 & 42648 & 1.067 & 0.000 & -19.845 \\
\hline \multirow{4}{*}{$\begin{array}{l}\text { Potential } \\
\text { Solar } \\
\text { Radiation } \\
\left(\mathrm{WH} / \mathrm{m}^{2}\right)\end{array}$} & $660-856788$ & 0 & 0.000 & 743104 & 18.592 & 0.000 & -0.21 \\
\hline & $856789-1839402$ & 18568 & 55.738 & 1236587 & 30.939 & 1.802 & 21.003 \\
\hline & $1839403-2322270$ & 14745 & 44.262 & 991562 & 24.808 & 1.784 & 21.589 \\
\hline & $2322271-2598972$ & 0 & 0.000 & 1025634 & 25.661 & 0.000 & 1 \\
\hline
\end{tabular}

$\mathrm{a}=$ Total number of pixels showing active rock glacier occurrence $=33313$

$\mathrm{b}=(\mathrm{a} / 33313) * 100$

$\mathrm{c}=$ Total number of pixels in domain $=3.996 .887$

$\mathrm{d}=(\mathrm{c} / 3996887) * 100$

$\mathrm{e}=\mathrm{b} / \mathrm{d}$ 
Table 6. Collinearity statistics.

\begin{tabular}{|l|c|c|}
\hline \multirow{2}{*}{ Model } & \multicolumn{2}{|c|}{ Collinearity Statistics } \\
\cline { 2 - 3 } & Tolerance & FIV: variance inflation factor \\
\hline Lithology & 0.858 & 1.166 \\
\hline Slope & 0.951 & 1.052 \\
\hline Aspect & 0.997 & 1.003 \\
\hline Elevation & 0.807 & 1.239 \\
\hline Potential Solar Radiation & 0.924 & 1.083 \\
\hline
\end{tabular}

The test proved that the equation and model could be admissible, because the values of Cox and Snell $\mathrm{R}^{2}(0.584)$ and Nagelkerke $\mathrm{R}^{2}(0.779)$ are greater than 0.2 (Clark and Hosking, 1986). The goodness of fit of our statistical model is based on Hosmer and Lemeshow Test (Table 7) and Pearson's chi-squared test (Table 8). These reveal that there is no multicollinearity among any of the variables and that they are weakly correlated with each other. In addition, Pearson correlations (Table 8) once again confirm that the variables used in the present study are only weakly correlated with each other, thus, they are considered independent variables.

Table 7. Hosmer and Lemeshow Test (H-L Test).

\begin{tabular}{|c|c|c|c|}
\hline Step & Chi squared & Gl. & Sig \\
\hline 1 & 7.678 & 8 & 0.466 \\
\hline
\end{tabular}

Table 8. Bilateral and Pearson correlation.

\begin{tabular}{|l|c|c|c|c|c|c|}
\hline & & Lithology & Slope & Aspect & Elevation & $\begin{array}{c}\text { Potential Solar } \\
\text { Radiation }\end{array}$ \\
\hline \multirow{2}{*}{ Lithology } & Pearson Correlation & 1 & 0.11 & 0.41 & 0.368 & 0.158 \\
\cline { 2 - 7 } & SIG (Bilateral) & & 0 & 0.064 & 0 & 0 \\
\hline \multirow{3}{*}{ Slope } & Pearson Correlation & 0.11 & 1 & 0.028 & 0.199 & 0.135 \\
\cline { 2 - 7 } & SIG (Bilateral) & 0 & & 0.205 & 0 & 0 \\
\hline \multirow{3}{*}{ Espect } & Pearson Correlation & 0.041 & 0.028 & 1 & 0.021 & -0.01 \\
\cline { 2 - 7 } & SIG (Bilateral) & 0 & 0.205 & & 0.338 & 0.654 \\
\hline \multirow{2}{*}{$\begin{array}{l}\text { Potential Solar } \\
\text { Radiation }\end{array}$} & Pearson Correlation & 0.368 & 0.199 & 0.021 & 1 & 0.253 \\
\cline { 2 - 7 } & SIG (Bilateral) & 0 & 0 & 0.338 & & 0 \\
\cline { 2 - 7 } & SIG (Bilateral) & 0 & 0 & 0.654 & 0 & 1 \\
\hline
\end{tabular}

Taking everything into account, active rock glacier occurrence is mainly influenced by elevation and, to a lesser extent, by lithology and aspect. As their elevation range had been divided into three zones: lower, middle and upper current periglacial environment belt; it was possible to analyze the altitudinal distribution in detail. The highest belt (4048 to $4225 \mathrm{~m}$ a.s.1.) presents the most suitable conditions for active rock glacier occurrence: $\mathrm{Fr}=6.237$ and $\mathrm{LR}=2.328$. The analysis of lithology influence over active rock glaciers demonstrates that they are mainly developed over Permo-Triassic volcanic complex rocks (PTrv). $\mathrm{Fr}=2.674$ and $\mathrm{LL}=1$; while aspect analyses show a major occurrence on south-facing slopes $(\mathrm{Fr}=2.661$ and $\mathrm{LR}=21.507)$. 


\section{Discussion}

The Central Andes of Argentina is the mountain range with the highest density of rock glaciers in the world (Trombotto et al., 2012). The results obtained in this paper show that rock glaciers and protalus ramparts are indeed abundant in the northern sector of the Central Andes of Argentina, with 405 rock glaciers and protalus ramparts occupying $3.14 \%$ of the total area $\left(630 \mathrm{~km}^{2}\right)$. Other rock glaciers inventories in the region show similar results as regards the spatial density of these landforms (Esper Angillieri, 2017; Trombotto et al., 2012; ING, 2016; Villarroel and Forte, 2020; Villarroel et al., 2018, 2020; Tapia Baldis, 2018).

Rock glaciers are generally easily recognized in the field or on satellite imagery. In their upper sector, they are usually delimited by a noticeable change in slope between the rockwall and the landform, while in their lower sector, the boundary is denoted by a frontal talus with a pronounced slope. On the surface, the presence of furrow and ridges or collapsed structures is frequent, in the form of thermokarst associated with ice melting. However, the delimitation of the landforms in the rooting zone or in the area of connection with other lobes presents some difficulties (Roer and Neynhuis, 2007). In order to avoid ambiguity and obtain a more accurate inventory, the mapping has been performed by two individuals and controlled with field information. Previous research, including that by Scotti et al. (2013) and Brardinoni et al. (2019), has also applied the methodology of using two or more mappers in the same sector to record rock glacier inventories. In this study, the uncertainty is relatively less, possibly because the landforms are clearly shaped and thus easily identified, even in the case of inactive rock glaciers.

One of the most significant aspects in arid regions is that intact rock glaciers and protalus ramparts are considered solid-water reserves (Scapozza et al., 2011; Jones et al., 2018; Villarroel et al., 2020) and indicators of mountain permafrost (Barsch, 1996; Haeberli et al., 2010). Therefore, the classification as active and inactive takes special relevance for the climatic and environmental information available because it is closely related to the capacity of these landforms to be solid-water reserves and/or water resources (Jones et al., 2018, 2019; Ohlanders et al., 2013; Villarroel et al., 2020). Despite the possible ambiguity, in several studies the state of activity has been assessed by taking into account morphological characteristics (Barsch 1996; Haeberli et al., 2010; Ikeda and Matsuoka 2006; Roer and Neynhuis, 2007; Esper Angillieri, 2010, 2017; Jones et al., 2019). The observed active and inactive rock glaciers are usually located in continuity, active overlapping inactive ones. A similar situation was found between inactive and fossil rock glaciers, where inactive shapes developed over fossil ones.

The minimum elevation of active rock glaciers is considered as altitudinal limit from which the permafrost develops (Barsch, 1996). Thus, the Current Periglacial Environment (where mountain permafrost exists) in the study area is above $3690 \mathrm{~m}$ a.s.l. Other studies in the Central Andes show similar elevations, for example: at a $34^{\circ} \mathrm{S}$ latitude, the lower elevation is $3750 \mathrm{~m}$ a.s.l. (Brenning and Trombotto, 2006); at a $30^{\circ} 50^{\prime}$ to $33^{\circ} 50^{\prime}$ latitude, it is $3700 \mathrm{~m}$ a.s.l. (Villarroel et al., 2018); at $31^{\circ} 50^{\prime}$ ', it is $3593 \mathrm{~m}$ a.s.1. (Villarroel and Forte, 2020) and at $32^{\circ} 20^{\prime}$, it is $3280 \mathrm{~m}$ a.s.l. (Forte, 2020). Regional data have shown that there is an important effect on latitude due to the increase in elevation of active rock glaciers from south to north (IGN, 2016; Villarroel et al., 2018). In addition, it has been shown that the cryosphere also changes latitudinally given the increasing aridity towards the north that enters the South American arid diagonal in the north of the country; and that the glacial environment is noticeably reduced, while the periglacial environment and the mountain permafrost develop more frequently (Garcia et al., 2017).

As regards the classification of intact rock glaciers, Barsch (1996) mentions two types of inactive rock glaciers: climatic or dynamic. In the first case, inactivity is due to the ice melting, while in the second case, the inactivity is due to the considerable distance between the surface of the rock glacier and the debris source. In the study region, rock glaciers have a small size and also a short length, hence it was assumed that activity could be mainly controlled by climatic variables. 
Protalus ramparts are considered an expression of current mountain permafrost creep (Barsch, 1996; Scapozza et al., 2011; Hedding, 2011; Scotti et al., 2013). This paper shows that these are the most frequent landforms (231). Thus, there is evidence of widespread current permafrost conditions in the study area.

The relationship between environmental variables (climatic, lithology, topographic and morphometric) and the spatial distribution of rock glaciers is essential for conducting regional studies on periglacial environment distribution. Especially in the case of high mountain areas, where poor accessibility reduces the chances of obtaining climatic data, while it steeply increases the costs of systematic field studies. In this paper, we present this spatial analysis using frequency ratio and logistic regression as statistical methods.

The results show that the occurrence of active rock glaciers is mainly influenced by their altitudinal distribution and, in the study area, all of them lie above $3600 \mathrm{~m}$ a.s.l. Thus, this altitude is assigned as the minimum elevation for the development of the current periglacial environment. Under this elevation, inactive rock glaciers and protalus ramparts can be found, thus it has been deemed an unstable periglacial environment area, where their existence is possible due to the terrain and environment capacities for permafrost conservation. The belt between 4048 and $4225 \mathrm{~m}$ a.s.1. presents the most suitable conditions for active rock glacier occurrence: $\mathrm{Fr}=6.237$ and $\mathrm{LR}=2.328$. These results are consistent with other similar researches performed in other regions, e.g.: Brenning (2005), Brenning and Trombotto (2006), Ikeda and Matsuoka (2006), Johnson et al. (2007) and Esper Angillieri, (2010, 2017).

Statistical analysis also shows that lithologic characteristics are a key variable for the occurrence of rock glaciers. Active rock glaciers are mainly found over Permo-Triassic volcanic complex rocks (PTrv), $\mathrm{Fr}=2.674$ and $492 \mathrm{LR}=1$. This lithology possibly affects the debris production (and their size), as well as the capacity of infiltration and water and ice storage of rock glaciers. Furthermore, it could influence their behavior since there are lithologies that favor rock glacier development, but in doing so, could also make these landforms prone to higher degradation. More specifically, due to their chemical composition, high porosity (availability for water infiltration) and/or subjection to a high degree of weathering, these rocks tend to have a greater capacity for the development of debris and, therefore, for rock glacier development and degradation (French and Williams, 2007; Johnson et al., 2007). For example, rocks from the PTrv unit (Permo-Triassic sedimentary, pyroclastic, subvolcanic and volcanic or plutonic rocks with hydrothermal alteration) evidence greater weathering and erosion processes, mainly cryoclastism. Hence, inactive rock glaciers are as common as active rock glaciers in such lithologies. On the other hand, there are other lithologies over which rock glaciers develop less frequently but seem to withstand environmental changes in a state of preservation for a quite longer period of time. Over these lithological units, there is usually a smaller number of inactive rock glaciers than active ones. The results of this work indicate that intrusive and granitic rocks, despite not being the most favorable rocks for periglacial landform development, seem to be a suitable lithology for active rock glacier conservation. While areas with lithologies as EOp, Mv, JK ism and DPig units, despite their favorable elevation, slope, aspect and solar radiation conditions for rock glacier occurrence, there are relatively rare, occupying only $0.4 \mathrm{~km}^{2}$ in total. Instead, active rock glaciers commonly locate in areas dominated by pyroclastic, subvolcanic and intrusive rocks of the Permo-Triassic volcanic complex (PTrv), covering $4.03 \mathrm{~km}^{2}$. Therefore, the study suggests some intriguing topics related to lithologies and their capacity for rock glacier development and/or conservation.

The larger number of rock glaciers is found in the Frío river basin $(n=15)$. Whereas the basin with the major development of active rock glaciers is found on the Bagre river watersheds $(n=12)$. Over the latter, the most favorable lithology and highest peaks are found.

Although intact rock glaciers and protalus ramparts are indicators of periglacial environment and mountain permafrost occurrence, different authors have indicated that the lower altitudinal limit of active rock glaciers represents the lower limit of discontinuous mountain permafrost (Brenning, 2005). 
In the study area, this limit is assigned at $3690 \mathrm{~m}$ a.s.l. and, in this paper, the resulting area is called 'current periglacial environment'. Above said elevation, the $90 \%$ of inactive rock glaciers and $61 \%$ of fossil rock glaciers are located. These results are consistent with the elevation of $3725 \mathrm{~m}$ a.s.l. as the lower limit of permafrost identified from geophysical surveys in three rock glaciers over the Frío river basin (Forte et al., 2013; Villarroel et al., 2020). In addition, two altitudinal units are differentiated below $3690 \mathrm{~m}$ a.s.1.: one between 3300 to $3690 \mathrm{~m}$ a.s.1., where there are protalus ramparts and inactive rock glaciers, an another below $3300 \mathrm{~m}$ a.s.l., where there is a large number of fossil rock glaciers and other periglacial landforms, indicating paleo-environmental conditions in favor of cryogenic processes. At $3375 \mathrm{~m}$ a.s.l., the altitudinal belt is considered an unstable periglacial environment, because the mean annual air temperature (MAAT) is $2.4{ }^{\circ} \mathrm{C}$ (Schreiber, 2015). However, the existence of inactive rock glaciers and protalus ramparts in this region demonstrates that elevation is not the only variable controlling the occurrence of periglacial landforms.

Another noteworthy topic is the influence of the subtropical position of the region over the distribution of periglacial landforms. The study area is located about $1000 \mathrm{~km}$ south of the Capricorn Tropic. This is reflected in their distribution with regards to the orientation of the slopes (aspect), along with a remarkable development and conservation on south-facing slopes $(\mathrm{Fr}=2.661$ and $\mathrm{LR}=21.507)$. On the other hand, slope and solar radiation are not considered significant variables for rock glacier occurrence. Solar radiation is high on the entire studied area, due to the semi-arid climate and the large number of sunny days. For active rock glacier occurrence, the most favorable solar radiation obtained from the frequency relation is the range between 857 and $1840 \mathrm{Kw} \cdot \mathrm{h} / \mathrm{m}^{2}(\mathrm{Fr}=1.802)$; while logistic regression shows the range between 1840 to $2322 \mathrm{Kw} \cdot \mathrm{h} / \mathrm{m}^{2}$ as the best condition. So, as also recorded by other studies (Esper Angillieri, 2010), solar radiation does not indicate a clear pattern or a significant influence over the occurrence of rock glaciers.

During recent years, activities related to mining projects have modified the landscape and the original environmental characteristics of the study area. If these projects become mines, they could affect the behavior of the natural hydrological and cryospheric systems significantly. Thus, the findings presented in this work constitute a contribution by documenting the original and natural number, features and distribution of rock glacier bodies currently present in the region.

\section{Conclusion}

An important periglacial environment development is evidenced in the study area. The environmental conditions are optimal for the development and conservation of cryospheric landforms with potential ice content in solid state, shape of intact rock glaciers or protalus ramparts.

The statistical methods used in this paper, show how five environmental variables influence the occurrence of active rock glaciers in a sector of the Central Andes of Argentina, obtaining valuable results for the assessment of the environmental situation of the region. The methodology applied reveals that the spatial distribution of active rock glaciers is influenced mainly by elevation, followed by lithology and aspect, and, to a lesser extent, by slope and solar radiation. The analysis of their spatial distribution in relation to aspect shows their larger development and conservation on south-facing slopes. The subtropical location of the study area seems to have a greater influence on their development than slope orientation.

Considering that elevation is the variable with the greatest influence in the occurrence of active rock glaciers, and that this aspect is also directly linked to air temperature, it is important to monitor the stability and behavioral changes of these landforms. Especially, taking into account the current context of increasing environmental temperatures and the potential of rock glaciers as water resources and reserves in many arid mountainous regions. 
Forte et al.

\section{References}

Atkinson, P., Jiskoot, H., Massari, R., Murray, T. 1998. Generalized linear modelling in geomorphology. Earth Surface Processes and Landforms 23 (13), 1185-1195. https://doi.org/10.1002/(SICI)10969837(199812)23:13<1185::AID-ESP928>3.0.CO;2-W

Ayalew, L., Yamagishi, H. 2005. The application of GIS-based logistic regression for landslide susceptibility mapping in the Kakuda-Yahiko Mountains, Central Japan. Geomorphology 65 (1-2), 15-31. https://doi.org/10.1016/j.geomorph.2004.06.010

Azócar, G.F., Brenning, A. 2010. Hydrological and Geomorphological Significance of Rock Glaciers in the Dry Andes, Chile $\left(27^{\circ}-33^{\circ} \mathrm{S}\right)$. Permafrost and Periglacial Processes 21, 42-53. https://doi.org/10.1002/ppp.669

Barsch, D., 1996. Rockglaciers. Indicators for the Present and Former Geoecology in High Mountain Environments Springer, Berlin.

Bonham-Carter, G.F. 1994. Geographic information systems for geoscientists-modeling with GIS. Computer Methods in the Geoscientists 13, 398.

Brardinoni, F., Scotti, R., Sailer, R., Mair, V. 2019. Evaluating sources of uncertainty and variability in rock glacier inventories. Earth Surface Processes and Landforms 44 (12), 2450-2466. https://doi.org/10.1002/esp.4674

Brenning, A. 2005. Climatic and geomorphological controls of rock glaciers in the Andes of Central Chile: Combining statistical modelling and field mapping. Ph.D. thesis. Humboldt Universität. Berlin, Alemania, $137 \mathrm{pp}$.

Brenning, A., Trombotto, D. 2006. Logistic regression modelling of rock glacier and glacier distribution: Topographic and climatic controls in the semi-arid Andes, Geomorphology 81, 141-154. https://doi.org/10.1016/j.geomorph.2006.04.003

Bruniard, E.D., 2014. La diagonal árida argentina: un límite climático real. Revista Geográfica 95, 5-20.

Clarck, W.A.V., Hosking, P.L. 1986. Statistical methods for geographers. John Wiley and Sons, 518 p., New York.

Colucci, R.R., Boccali, C., Žebre, M., Guglielmin, M. 2016. Rock glaciers, protalus ramparts and pronival ramparts in the south-eastern Alps. Geomorphology 269, 112-121. https://doi.org/10.1016/j.geomorph.2016.06.039

Colucci, R.R., Forte, E., Zebre, M., Maset, E., Zanetti, C., Guglielmin, M. 2019. Is that a relict rock glacier? Geomorphology 330, 177-189. https://doi.org/10.1016/j.geomorph.2019.02.002

Corripio, J., Purves, R., Rivera, A. 2007. Modeling climate-change impacts on mountain glaciers and water resources in the Central Dry Andes, Darkening Peaks: Glacier Retreat, Science and Society, University of California Press, pp. 126-136, USA.

Esper Angillieri, M.Y., 2010. Application of frequency ratio and logistic regression to active rock glacier occurrence in the Andes of San Juan, Argentina. Geomorphology 114, 396-405. https://doi.org/10.1016/j.geomorph.2009.08.003

Esper Angillieri, M.Y. 2017. Permafrost distribution map of San Juan Dry Andes (Argentina) based on rock glacier sites. Journal of South American Earth Sciences $73 \quad$ (C), 42-49. https://doi.org/10.1016/j.jsames.2016.12.002

Forte, A.P. 2020. Evolución reciente de glaciares en las nacientes del arroyo Laguna Blanca y su importancia hidrológica. Calingasta, San Juan, Argentina. Tesis Doctoral. Facultad de Ciencias Exactas, Físicas y Naturales. Universidad Nacional de San Juan.

Forte, A.P., Güell, A.E., Villarroel, C.D. 2013. Tomografía sísmica en glaciares de escombros en las nacientes del arroyo Los Patos Norte. Calingasta, San Juan, Argentina. Boll. Geof. Teor. Appl. 25, 263-265.

Forte, A.P., Villarroel, C.D., 2019. Reconstrucción geomorfológica del último máximo glaciar en la cuenca del río San Juan, Argentina. Cuaternario y Geomorfología 33, 62-82.

French, H. M., Williams, P. 2007. The periglacial environment (Vol. 458). Chichester: John Wiley and Sons. 
García Piña A., Ulloa C., Amigo G., Milana J.P., Medina C., 2017. An inventory of cryospheric landforms in the arid diagonal of South America (high Central Andes, Atacama region, Chile). Quaternary International 1-16. https://doi.org/10.1016/j.quaint.2017.04.033

Haeberli W., Noetzli J., Arenson L., Delaloye R., Gärtner-Roer I., Gruber S., Isaksen K., Kneisel C., Krautblatter M., Phillips M., 2010. Mountain permafrost: development and challenges of a young research field. Journal of Glaciology 56 (200), 1043-1058. https://doi.org/10.3189/002214311796406121

Harrisson, S., Glasser, N., Winchester, V., Haresign, E., Warren, C.H., Duller, G., Bailey, R., Ivy-Ochs, S., Jansson, K., Kubik, P., 2008. Glaciar León, Chilean Patagonia: late-Holocene chronology and geomorphology. The Holocene 18 (4), 643-652. https://doi.org/10.1177/0959683607086771

Hedding, D.W., 2011. Pronival rampart and protalus rampart: A review of terminology. Journal of Glaciology 57 (206), 1179-1180. https://doi.org/10.3189/002214311798843241

Hosmer, D.W., Jovanovic, B., Lemeshow, S. 1989. Best subsets logistic regression. Biometrics 45 (4), 1265-1270. https://doi.org/10.2307/2531779

Ikeda, A., Matsuoka, N. 2006. Pebbly versus bouldery rock glaciers: Morphology, structure and processes. Geomorphology 73, 279-296. https://doi.org/10.1016/j.geomorph.2005.07.015

ING. 2016. Informe de la subcuenca del río Blanco, Cuenca del río San Juan. Inventario Nacional de Glaciares. Ministerio de Ambiente y Desarrollo Sustentable. IANIGLA- CCT Mendoza - CONICET.

Johnson, B., Thackray, G., Van Kirk, R. 2007. The effect of topography, latitude and lithology on rock glacier distribution in Lemhi Range, central Idaho, USA, Geomorphology 91, 38-50. https://doi.org/10.1016/j.geomorph.2007.01.023

Jones, D.B., Harrison, S., Anderson, K., Selley, H.L., Wood, J.L., Betts, R.A. 2018. The distribution and hydrological significance of rock glaciers in the Nepalese Himalaya. Glob. Planet. Chang. 160 (C), 123142. https://doi.org/10.1016/j.gloplacha.2017.11.005

Jones, D.B., Harrison, S., Anderson, K., Walley, B. 2019. Rock glaciers and mountain hydrology: A review. EarthScience Reviews 193, 66-90. https://doi.org/10.1016/j.earscirev.2019.04.001

Kääb, A., Frauenfelder, R., Roer, I., 2007. On the response of rockglacier creep to surface temperature increase. Global and Planetary Change 56, 172-187. https://doi.org/10.1016/j.gloplacha.2006.07.005

Menard, S. 2000. Coefficients of determination for multiple logistic regression analysis. The American Statistician 54(1), 17-24.

Monnier, S., Kinnard, C. 2013. Internal structure and composition of a rock glacier in the Andes (upper Choapa valley, Chile) using borehole information and ground-penetrating radar. Annals of Glaciology 54 (64), 61-72. https://doi.org/10.3189/2013AoG64A107

Ohlanders, N., Rodríguez, M., McPhee, J. 2013. Stable water isotope variation in a Central Andean watershed dominated by glacier and snowmelt. Hydrology and Earth System Sciences 17 (3), 1035-1050. https://doi.org/10.5194/hess-17-1035-2013

Palacios, D., Stokes, C. R., Phillips, F. M., Clague, J.J., Alcalá-Reygosa, J., Andrés, N., Angel, I., Blard, P.H., Briner, P.J., Hall, B.L., Dahms, D., Heins, A.S., Jomelli, V., Mark, B.G., Martine, M.A., Moreno, P., Riedel, J., Sagredo, E., Stansell, N.D., Vázquez-Selem, L., Vuille, M., Ward, D.J. 2020. The deglaciation of the Americas during the Last Glacial Termination. Earth-Science Reviews 203, 103113. https://doi.org/10.1016/j.earscirev.2020.103113

Paul, F., Barry, J.G., Cogley, H., Frey, H., Haeberli, W., Ohmura, A., Ommanney, C.S.L., Raup, B., Rivera, A., Zemp, M., 2010. Guidelines for the compilation of glacier inventory data from digital sources. WGMS, GLIMS, Globglacier, University of Zürich.

Rivera, J.A., Penalba, O.C., Betolli, M.L., 2013. Inter-annual and inter-decadal variability of dry days in Argentina. International Journal Climatology 33, 834-842. https://doi.org/10.1002/joc.3472

Roer, I., Nyenhuis, M. 2007. Rock glacier activity studies on a regional scale: comparison of geomorphological mapping and photogrammetric monitoring. Earth Surface Processes Landforms 32, 1747-1758. https://doi.org/10.1002/esp.1496

Rolleri, E.O., Criado R.P., 1970. Geología de la provincia de Mendoza. $4^{a}$ Jornadas Geológicas Argentinas, Actas 2, 1-60. 
Scapozza, C., Lambiel C., Baron L., Marescot L., Reynard E., 2011. Internal structure and permafrost distribution in two alpine periglacial talus slopes, Valais, Swiss Alps. Geomorphology 132 (3-4), 208221.https://doi.org/10.1016/j.geomorph.2011.05.010

Schreiber, E., 2015. Modeling the distribution of Mountain Permafrost in Central Andes, San Juan, Argentina. M. $\mathrm{S}$. Thesis, University of Delaware, United States.

Scotti, R., Brardinoni, F., Alberti, S., Frattini, P., Crosta, G.B. 2013. A regional inventory of rock glaciers and protalus ramparts in the central Italian Alps. Geomorphology 186, 136-149. https://doi.org/10.1016/j.geomorph.2012.12.028

SEGEMAR, 2008. SIG SEGEMAR, 2016. http://sig.segemar.gov.ar/, last access: 7 September 2016.

Strecker, M.R., Alonso, R.N., Bookhagen, B., Carrapa, B., Hilley, G.E., Sobel, E. R., Trauth, M.H., 2007. Tectonics and climate of the southern central Andes. Annual Review of Earth and Planetary Sciences 35, 747-787.

Tapia Baldis, C. 2018. Distribución y características del ambiente periglaciar en el extremo oeste del departamento Calingasta, provincial de San Juan, Argentina. Tesis Doctoral. Facultad de Ciencias Exactas, Físicas y Naturales. Universidad Nacional de San Juan.

Travis, M.R., Elsener, G.H., Iverson, W.D., Johnson, C.G. 1975. View it computation of seen areas, slope, and aspect for land-use planning. US Department of Agriculture Forest Service General Technical Report PSW, Pacific Southwest Forest and Range Experimental Station, Berkeley, California, U.S.A, 11, 70 p.

Trombotto, D., Lenzano, M.G., Castro, M. 2012. Inventory and monitoring of cryoforms and cryogenic processes in the Central Andes of Mendoza, Argentina: birth and extinction of a periglacial lake. $10^{\circ}$ International Conference on Permafrost, Proceedings 1, 419-424, Salekhard, Russia.

Villarroel, C.D. 2019. Características hidrológicas del ambiente periglacial de montaña y estructura interna de glaciares de escombros en los Andes centrales de San Juán. Tesis Doctoral. Facultad de Ciencias Exactas, Físicas y Naturales. Universidad Nacional de San Juan.

Villarroel, C.D., Tamburini Beliveau, G., Forte, A.P., Monserrat, O., Morvillo, M. 2018. DInSAR for a Regional Inventory of Active Rock Glaciers in the Dry Andes Mountains of Argentina and Chile with Sentinel-1 Data. Remote Sensing 10, 1-21. https://doi.org/10.3390/rs10101588

Villarroel, C.D., Forte, A. P., 2020. Spatial distribution of active and inactive rock glaciers and protalus ramparts in a sector of the Central Andes of Argentina. Cuadernos de Investigación Geográfica (Geographical Research Letters) 46 (1), 141-158. https://doi.org/10.18172/cig.4272

Villarroel, C.D., Forte, A.P., Ortiz, D.A., Beliveau, G.T., Güell, A. 2020. Active layer and permafrost thickness in rock glaciers derived from geophysical methods in the semiarid Andes of Argentina. Geomorphology, 107249. https://doi.org/10.1016/j.geomorph.2020.107249

Whalley W.B., Azizi F., 2003. Rock glaciers and protalus landforms: Analogous forms and ice sources on Earth and Mars. Journal of Geophysical Research: Planets 108-E4. https://doi.org/10.1029/2002JE001864 